\title{
Modeling degradation ratios and nutrient availability of anthocyanidin-accumulating $L c$-alfalfa populations in dairy cows
}

\author{
A. Jonker, ${ }^{\star} \dagger^{1}$ M. Y. Gruber, $†$ Y. Wang,‡ B. Coulman,§ A. Azarfar, ${ }^{\star}$ J. J. McKinnon, ${ }^{\star}$ D. A. Christensen, ${ }^{\star}$ \\ and $\mathbf{P} . \mathbf{Y u}^{*}$ \\ *Department of Animal and Poultry Science, University of Saskatchewan, 51 Campus Drive, Saskatoon, SK, Canada, S7N 5A8 \\ †Saskatoon Research Center, Agriculture and Agri-Food Canada, 107 Science Place, Saskatoon, SK, Canada, S7N 0X2 \\ łLethbridge Research Center, Agriculture and Agri-Food Canada, 5403 1st Ave. South, Lethbridge, AB, Canada, T1J 4B1 \\ §Department of Plant Sciences, University of Saskatchewan, 51 Campus Drive, Saskatoon, SK, Canada, S7N 5A8
}

\begin{abstract}
Dairy cattle eating fresh or ensiled alfalfa as the main portion of their diet often have low protein efficiency because of the rapid initial rate of ruminal protein degradation of fresh and ensiled alfalfa. Ruminal protein degradation of alfalfa might be reduced by introducing a gene that stimulates the accumulation of mono- or polymeric anthocyanidins in alfalfa. The objectives of this study were to fractionate protein and carbohydrates by in situ and chemical approaches, to evaluate in situ ruminal degradation characteristics and synchronization ratios, to determine protein availability to dairy cattle using the 2007 digestible intestinal protein/ rumen-degraded protein balance (DVE/OEB) protein system, and to determine net energy for lactation using the Dutch net energy for lactation (VEM) system for 3 newly developed transgenic winter hardy anthocyanidin-accumulating $\mathrm{T}_{1} L c$-alfalfa populations. These $\mathrm{T}_{1}$ $L c$-alfalfa populations, called ${ }^{\mathrm{T} 1}$ Beav $L c 1,{ }^{\mathrm{T} 1} \mathrm{Ramb} L c 3$, and ${ }^{\mathrm{Tl}}$ Rang $L c 4$, had an average anthocyanidin accumulation of $163.4 \mu \mathrm{g} / \mathrm{g}$ of DM, whereas AC Grazeland (selected for a low initial rate of degradation) did not accumulate anthocyanidin. The basic chemical composition of the original samples, soluble and potentially degradable fractions, and degradation characteristics of crude protein and carbohydrates were similar in $\mathrm{T}_{1}$ $L c$-alfalfa and AC Grazeland. The undegradable in situ crude protein and neutral detergent fiber fraction had $1.3 \%$ lower $\mathrm{CP}$ and $4.8 \%$ lower $\mathrm{CHO}$, respectively, in $\mathrm{T}_{1} L c$-alfalfa compared with the amounts in AC Grazeland. The $\mathrm{T}_{1} L c$-alfalfa had a $0.34 \mathrm{MJ} / \mathrm{kg}$ of $\mathrm{DM}$ higher calculated net energy for lactation and $1.9 \%$ of $\mathrm{CP}$ higher buffer soluble protein compared with that in AC Grazeland. By the protein evaluation model, it was predicted that $\mathrm{T}_{1} L c$-alfalfa tended to have 11.9, 6.9, and $8.4 \mathrm{~g} / \mathrm{kg}$ of DM higher rumen degradable protein,
\end{abstract}

Received July 7, 2010.

Accepted November 16, 2010.

${ }^{1}$ Corresponding author: arj051@mail.usask.ca
OEB, and intestinal available protein, respectively, compared with the amounts in AC Grazeland. The hourly OEB included an initial and substantial peak (oversupply) of protein relative to energy, which was highest in ${ }^{\mathrm{T1}}$ Rang $L c 4$ and lowest in ${ }^{\mathrm{T} 1} \mathrm{Ramb} L c 3$. The hourly OEB between 4 and $24 \mathrm{~h}$ was similar and more balanced for all 4 alfalfa populations. In conclusion, $\mathrm{T}_{1}$ $L c$-alfalfa accumulated anthocyanidin, tended to have higher predicted intestinal protein availability, and had higher predicted net energy of lactation availability for dairy cattle than did AC Grazeland.

Key words: anthocyanidin-accumulating alfalfa, DVE/OEB 2007 protein system, ruminal protein-toenergy ratio and synchronization, dairy cattle

\section{INTRODUCTION}

Alfalfa (Medicago sativa L.), also known as lucerne, is one of the main forages in the world, which makes it an important protein source in ruminant rations. When alfalfa is grazed, the costs for milk and meat production are decreased (Rotz, 1996). However, the rapid initial rate of ruminal protein degradation, which is prevalent in freshly ingested alfalfa pasture, makes protein the most limiting nutritional factor for the ruminant (Barry, 1981; Dhiman and Satter, 1993; Broderick, 1995) and is the main cause of pasture bloat, an often fatal disorder (Howarth, 1975; McMahon et al., 2000). Rapid protein degradation also causes an imbalance between the supply of $\mathrm{N}$ and energy in the rumen for microbial protein synthesis. Excess ruminal protein is mainly absorbed as ammonia $\left(\mathrm{NH}_{3}\right)$ by the rumen and is mainly lost to the animal (Broderick, 1995; Yu et al., 2004). Excessive ruminal protein degradation also results in a smaller portion of dietary protein escaping to the lower digestive tract, a process which is required for optimum animal performance of high-producing cattle (Dhiman and Satter, 1993; Klopfenstein, 1996).

Secondary plant metabolites such as monomeric anthocyanidins and polymeric anthocyanidins (condensed tannins) may decrease ruminal protein degradation by 
precipitating dietary protein (Stafford, 1990; Wang et al., 2006a) and increasing the portion of protein escaping ruminal degradation (Broderick, 1995; Aerts et al., 1999). At the low $\mathrm{pH}$ present in the abomasum, protein is released from the polymeric-anthocyanidin/protein complex, which might increase the availability of amino acids for absorption in the small intestine (Waghorn et al., 1987; Bermingham et al., 2001). However, polymeric anthocyanidins do not accumulate in alfalfa forage (Goplen et al., 1980). Using a whole-farm model, it was predicted that protein supplementation could be decreased by $60 \%$ if alfalfa accumulated polymeric anthocyanidins in the forage. This, in turn, would increase net return by $12 \%$ for dairy farms (Bouton, 2008).

Ray et al. (2003) transformed alfalfa with a maize anthocyanidin-regulating $\beta H L H L E A F C O L O R(\boldsymbol{L c})$ gene to develop new genotypes that accumulate monomeric or polymeric anthocyanidins in the forage. Wang et al. (2006b) found that the initial in vitro rate of nitrogen and DM degradation for $\mathrm{T}_{0} L c$-alfalfa genotypes was decreased compared with that of their nontransgenic parent genotype. However, their survival was poor under western Canadian conditions, and 3 of these genotypes had to be crossed with western Canadian varieties to develop winter-hardy $\mathrm{T}_{1} L c$-alfalfa populations. Coulman et al. (2000) reviewed the development of AC Grazeland, an alfalfa variety with a low initial rate of degradation, reduced bloat incidence, reduced leaf-to-stem ratio, and thicker leaf cell walls (Coulman et al., 1998, 2000), but this variety does not feature enhanced forage anthocyanidins. The lower initial degradation rate of $\mathrm{AC}$ Grazeland has the potential to change the site of nutrient supply in the digestive tract of the ruminant, but this has not been tested.

Feed material can be evaluated by in vivo experiments. However, when sample amount is limited or a large number of treatments is tested, one can use modeling as an alternative approach. Several mathematical models are available for diet formulation of dairy cattle. Input values for these models can be generated by chemical analysis or in vitro and in situ techniques (Sniffen et al., 1992; Tamminga et al., 2007). With these input values, one can calculate nutrient availability in the rumen for microbial protein synthesis, nutrient availability in the small intestine for absorption by the animal, and amount of nutrients completely lost to the animal. The recently revised (2007) digestible intestinal protein/ rumen-degraded protein balance (DVE/OEB) protein system uses a more advanced in situ fractionation scheme to fractionate $\mathrm{CP}$ and carbohydrates (CHO) compared with that of previous protein systems. This revised protein system uses individual $\mathrm{CP}$ and $\mathrm{CHO}$ fractions to calculate rumen-degradable fractions and rumen microbial protein synthesis (MCPr); previous protein systems used total rumen available energy to calculated MCPr (Tamminga et al., 2007). Thus, the new DVE/OEB system provides a more detailed evaluation of feed digestion in the ruminant.

The objectives of this study were to evaluate transgenic winter-hardy anthocyanidin-accumulating $\mathrm{T}_{1} \mathrm{Lc}$ alfalfa populations and the nontransgenic alfalfa variety AC Grazeland for nutrient availability to dairy cattle using modeling. We fractionated protein and energy of these 2 types of germplasm by in situ and chemical approaches and evaluated in situ ruminal degradation characteristics and synchronization ratios between protein and energy in the rumen. We also calculated protein availability in the rumen and small intestine based on in situ input values using the updated 2007 DVE/OEB protein system. Finally, we calculated energy values for lactation based on the Dutch net energy for lactation (VEM) system.

\section{MATERIALS AND METHODS}

\section{Alfalfa Material}

The $\mathrm{T}_{1}$ transgenic $L c$-alfalfa populations (Jonker et al., 2010) used in this study were developed at Forage Genetics International (West Salem, WI) by manually crossing $3 \mathrm{~T}_{0}$ transgenic $L c$-alfalfa genotypes ( $L c 1, L c 3$, and $L c 4$; Wang et al., 2006b) with several genotypes selected for winter hardiness from 3 nontransgenic western Canada-adapted alfalfa varieties (Beaver, Rambler, and Rangelander) to generate ${ }^{\mathrm{T} 1}$ Beav $L c 1,{ }^{\mathrm{T} 1} \operatorname{Ramb} L c 3$, and ${ }^{\mathrm{T} 1}$ Rang $L c 4$, respectively. The ${ }^{\mathrm{T} 1} L c$-alfalfa populations were compared with alfalfa variety AC Grazeland, which was selected earlier for a low initial rate of degradation and has been shown to reduce bloat in grazing cattle (Coulman et al., 2000). The ${ }^{\mathrm{T} 1} L c$-alfalfa populations were grown for approximately 6 mo from seed in a greenhouse. Sheared alfalfa plants were then transplanted into rows $(75 \mathrm{~cm}$ between rows; $15 \mathrm{~cm}$ between plants) in the dark brown soil in a Canadian Food Inspection Agency (CFIA)-approved experimental field at the Saskatoon Research Centre farm of Agriculture and Agri-Food Canada (AAFC) on August 24, 2006, and June 5, 2007. The AC Grazeland plants were dug up in the first week of June 2008 from a breeder's field at AAFC Indian Head (SK, Canada) and transplanted into the experimental field with ${ }^{\mathrm{T1}} \mathrm{Lc}$ alfalfa populations.

Field-grown alfalfa plants were harvested manually with shears at $c a .5 \mathrm{~cm}$ above ground level on July 24 and August 13 of 2008 at a vegetative pre-bud stage (according to CFIA-imposed confined field trail regulations). Transgenic ${ }^{\mathrm{T} 1} L c$ plants were sorted visually in the field based on forage color (green and purple-green). 
Purple-green ${ }^{\mathrm{T} 1} L c$-alfalfa and AC Grazeland forage were stored at $-20^{\circ} \mathrm{C}$ pending analysis. Transgenic plants had been analyzed previously for the presence of the $L c$ gene (Jonker et al., 2010).

\section{In Situ Rumen Incubation}

For in situ rumen incubations, 3 rumen fistulated, nonpregnant, dry Holstein-Friesian cows were used, which had been reviewed and approved by the CFIA and by the Animal Care Committee of the University of Saskatchewan (animal use protocol \# 19910012). Cows were individually housed in pens at the experimental farm of the University of Saskatchewan (Saskatoon, SK, Canada) and were cared for according the Canadian Council on Animal Care guidelines (CCAC, 1993). The cows had free access to water and were fed $15 \mathrm{~kg}$ of $\mathrm{DM} / \mathrm{d}$ of a TMR twice daily in equal portions at 0800 and $1600 \mathrm{~h}$. The TMR consisted of (\% of DM) $55 \%$ barley silage, $12.5 \%$ alfalfa hay, $5 \%$ dehydrated alfalfa, and $27.5 \%$ concentrates, as described in $\mathrm{Yu}$ et al. (2009).

Prior to in situ incubations, frozen alfalfa samples were freeze-dried and ground to pass through a 2-mm screen using a cyclonic mill (Retsch SM-3000, Brinkmann Instruments, ON, Canada). In situ ruminal degradation kinetics were determined as described by $\mathrm{Yu}$ et al. (2004), using number-coded nylon bags $(10 \times$ $20 \mathrm{~cm}$, pore size $40 \mu \mathrm{m}$, Nitex 03-41/31 monofilament open mesh fabric, ScreenTech, Mississagua, ON, Canada). Approximately $5 \mathrm{~g}$ of freeze-dried alfalfa sample was placed into each bag, resulting in a sample-to-bag surface ratio of approximately $28 \mathrm{mg} / \mathrm{cm}^{2}$. Filled bags were incubated in the rumen for $72,36,12,6$, and $2 \mathrm{~h}$ by the "all-out method." Immediately after retrieval, all bags were placed in a bucket with cold tap water to stop microbial fermentation and then washed 5 times manually in cold tap water, followed by oven drying at $55^{\circ} \mathrm{C}$ for $48 \mathrm{~h}$.

The 0-h incubation samples were washed by the procedure described by Azarfar et al. (2007a) to fractionate the washable $(\mathbf{W})$ fraction into a truly soluble $(\mathbf{S})$ washable fraction and a washable insoluble (WI) fraction. Briefly, the 0-h bags containing ca. $5 \mathrm{~g}$ of sample were placed into $250-\mathrm{mL}$ polypropylene tubes with 20 $\mathrm{mL}$ of distilled water per $1 \mathrm{~g}$ of alfalfa present in the bag and shaken at $150 \mathrm{rpm}$. After $1 \mathrm{~h}$, the nylon bags were removed from the tubes and dried at $55^{\circ} \mathrm{C}$ for 48 $\mathrm{h}$. The remaining washout fraction in the tube was filtered through filter paper (Whatman \#54; pore size 20 $\mu \mathrm{m})$ and the filter paper with residue (WI) was dried in an oven for $24 \mathrm{~h}$ at $55^{\circ} \mathrm{C}$. Because the WI residue on the filter paper was less than $0.001 \mathrm{~g}$ (data not shown), for the purpose of modeling, it was assumed that the
$\mathrm{W}$ fraction equaled the $\mathrm{S}$ fraction. Incubation residues from the treatment bags were combined within time per incubation run.

\section{Chemical Analysis}

Prior to chemical analysis, original freeze-dried alfalfa samples and dried rumen-incubated residues were ground to pass through a 1-mm screen using a centrifugal mill (Retsch ZM-100, Brinkmann Instruments). Original alfalfa samples and rumen-incubated residues were analyzed for DM, ash, and $\mathrm{CP}$ according to AOAC (1990). Crude protein $(\mathrm{N} \times 6.25)$ was analyzed by flash combustion using a Leco FP 528 analyzer (Leco Corporation, St. Joseph, MI). The NDF (determined with heat-stable $\alpha$-amylase for original samples and rumen-incubated residues, and with sodium sulfite for rumen-incubated residues), ADF, and acid detergent lignin (ADL) concentrations were determined by the method of Van Soest et al. (1991). The NDF and ADF residues for original samples were corrected for proteindetermined neutral detergent-insoluble protein and acid detergent-insoluble protein (ADIP) content using the Kjeldahl-N method (Kjeltec $1030 \mathrm{~N}$ autotitrator, Foss, Höganäs, Sweden) as described by Licitra et al. (1996). Nonprotein $\mathrm{N}$ remaining soluble in trichloroacetic acid and CP soluble in borate/phosphate buffer (BSP) were analyzed in original samples by the Kjeldahl-N method (Licitra et al., 1996). Additionally, original samples were analyzed for fat content by ether extraction (EE; AOAC, 1990) and for ethanol-soluble carbohydrates according to Hall et al. (1999). Total CHO content was calculated in \% of DM as $100-($ ash $+\mathrm{EE}+\mathrm{CP})$ according to the NRC (2001).

\section{Protein and Carbohydrate Profiling}

Protein and carbohydrates each were fractionated into soluble fractions, insoluble potentially degradable fractions, and undegradable fractions based on chemical analysis using the Cornell Net Carbohydrate and Protein System (CNCPS; Sniffen et al., 1992; Tylutki et al., 2008) and based on in situ incubations described in the 2007 version of the DVE/OEB system (Tamminga et al., 2007; Table 1). Degradation rates $\left(\boldsymbol{K}_{d}\right)$ for the potential degradable $(\boldsymbol{D})$ fraction of CP, NDF, residual nonstarch polysaccharides (RNSP), and OM were calculated using an exponential mathematical model as described by Robinson et al. (1986):

$$
R(t)=U+D \times \exp K_{d}{ }^{-K_{d}(t-l a g)},
$$

where $R$ is the residue (\%) of the incubated sample, $U$ is the undegradable fraction, $t$ is time of rumen incuba- 
tion (h), and lag is the lag time before degradation initiates. The parameters of the exponential model were calculated using PROC NLIN (nonlinear) from SAS (SAS Institute, 2003) with iterative least squares regression (Gauss-Newton method). Rumen-degradable fractions were calculated as described in Table 2. Rumen degradability was calculated for each in situ fraction (S, WI, and D) as described in Table 2, with values for fractional rate of passage $\left(\boldsymbol{K}_{p}\right)$ and $K_{d}$ described in Table 1 . Hourly rumen degradability was calculated as

$$
\text { In situ fraction } \times K_{d} /\left(K_{d}+K_{p}\right) \times\left[1-\exp ^{-t\left(K_{d}+K_{p}\right)}\right] \text {. }
$$

Ratios of $\mathrm{N}: \mathrm{CHO}(\mathrm{g} / \mathrm{kg})$ were calculated for total as well as hourly rumen-degradable N-to-CHO fractions.

\section{Modeling Nutrient Availability}

The 2007 DVE/OEB protein system (Tamminga et al. (2007) was used to predict feed protein quality using equations which calculate OEB and DVE (also called metabolizable protein in the CNCPS protein evaluation system; Sniffen et al., 1992; Table 2).

The $\mathrm{NE}_{\mathrm{L}}$ of alfalfa was calculated using equations from the VEM energy system described in Table 2 (Van Es, 1978). However, ME was calculated as described on the Dutch Product Board of Animal Feed (PDV) website (PDV, 2005) because the PDV recommended replacing the original ME equation of the VEM energy system described by Van Es (1978) for roughage like alfalfa with this new ME equation (Table 2).

Equations from the CVB (2005; Dutch Central Feed Office, part of PDV) were used to calculate potential fat/protein-corrected milk production $(\boldsymbol{F P C M})$ from $\mathrm{NE}_{\mathrm{L}}\left(\mathbf{F P C M} \_\mathbf{N E}_{\mathbf{L}}\right)$ and DVE $(\mathbf{F P C M}$ _DVE $)$. Fat/ protein-corrected milk is defined as milk with $4 \%$ of fat and $3.3 \%$ of protein $(\mathrm{CVB}, 2005)$. Intake $\mathrm{NE}_{\mathrm{L}} / \mathrm{DVE}$ was calculated for a $650-\mathrm{kg}$ Holstein-Friesian cow in second or later lactation with a DMI of $15 \mathrm{~kg} / \mathrm{d}$ grazing on alfalfa pasture (Castillo et al., 2006). This type of cow requires $864 \mathrm{KJ} / \mathrm{d}(772 \mathrm{KJ} / \mathrm{d}+12 \%$ of extra energy required for grazing) and $119 \mathrm{~g}$ of $\mathrm{DVE} / \mathrm{d}$ for maintenance (CVB, 2005). Intake $\mathrm{NE}_{\mathrm{L}} / \mathrm{DVE}$ minus maintenance $\mathrm{NE}_{\mathrm{L}} / \mathrm{DVE}$ leaves any remaining $\mathrm{NE}_{\mathrm{L}} /$ DVE available for milk production, and this available $\mathrm{NE}_{\mathrm{L}} / \mathrm{DVE}$ can be used to calculate the potential FPCM using the following 2 equations (CVB, 2005):

$$
\begin{gathered}
\text { FPCM_NE } \mathrm{L}_{\mathrm{L}}=440 \times F P C M+0.73 \times F P C M^{2} \text { and } \\
\mathrm{FPCM} \_\mathrm{DVE}=1.396 \times \mathrm{P}+0.000195 \times \mathrm{P}^{2},
\end{gathered}
$$

where $\mathrm{P}$ is milk protein production per day $(\mathrm{g} / \mathrm{d})$.

\section{Statistical Analysis}

The effect of alfalfa populations on measured parameters was analyzed using PROC MIXED of SAS 9.2 (SAS Institute, 2003). The statistical model used to analyze the chemical composition of the original sample was

$$
Y_{i j}=\mu+T_{i}+H_{j}+\varepsilon_{i j}
$$

where $Y_{i j}$ is the dependent variable, $\mu$ is the general mean, $T_{i}$ is the fixed effect of treatment $\left(i=4 ;{ }^{\mathrm{T} 1} \mathrm{Bea}-\right.$ $\mathrm{v} L c 1,{ }^{\mathrm{T} 1} \operatorname{Ramb} L c 3,{ }^{\mathrm{T} 1} \operatorname{Rang} L c 4$, and AC Grazeland), $H_{j}$ is the random effect of harvest date $(j=2$; July 24 or August 13, 2008), and $\varepsilon_{i j}$ is the residual error.

The statistical model used to analyze in situ fractions and degradation and calculated nutrient availability was

$$
Y_{i j}=\mu+T_{i}+R_{j}+\varepsilon_{i j}
$$

where $Y_{i j}$ is the dependent variable, $\mu$ is the general mean, $T_{i}$ is the fixed effect of treatment $\left(i=4 ;{ }^{\mathrm{T1}} \mathrm{Bea}\right.$ $\mathrm{v} L c 1,{ }^{\mathrm{T} 1} \operatorname{Ramb} L c 3,{ }^{\mathrm{T} 1} \operatorname{Rang} L c 4$, and AC Grazeland), $R_{j}$ is the random effect of incubation run $(j=2 ; 1$ and 2 ), and $\varepsilon_{i j}$ is the residual error. Differences between in situ and chemical fractions were analyzed by a paired $t$-test using PROC TTEST of SAS 9.2 (SAS Institute, 2003). The Fisher protected LSD test was used for multiple treatment comparisons using the LSMEAN statement of SAS 9.2 (SAS Institute, 2003) with letter groupings obtained using the SAS pdmix800 macro (Saxton, 1998). Contrasts in SAS were used to compare the mean of ${ }^{\mathrm{T} 1} L c^{1,3,4}$-alfalfa $\left({ }^{\mathrm{T} 1} \mathrm{Beav} L c 1+{ }^{\mathrm{T} 1} \mathrm{Ramb} L c 3\right.$ $+{ }^{\mathrm{T} 1}$ Range $\left.L c 4\right)$ with AC Grazeland. For the different statistical tests, significance was declared at $P \leq 0.05$ and trends at $P \leq 0.10$, unless otherwise stated.

\section{RESULTS AND DISCUSSION}

\section{Anthocyanidin Concentration and Fiber Levels in ${ }^{T 1}$ LC-Alfalfa and AC Grazeland}

The $3{ }^{\mathrm{T} 1} L c$-alfalfa populations harvested in 2008 had an average forage anthocyanidin level of $163.4 \mu \mathrm{g} / \mathrm{g}$ of DM, whereas AC Grazeland forage harvested from the same field at the same time did not accumulate anthocyanidins at all (Table 3). The anthocyanidin level of these ${ }^{\mathrm{T} 1} L c$-populations was higher than that previously found for their $\mathrm{T}_{0} L c$-alfalfa parent genotypes harvested in 2001 and 2002 at the same field site (96.9 to 136.4 $\mu \mathrm{g} / \mathrm{g}$ of DM; Wang et al., 2006b), but lower than the anthocyanidin content $(232 \mu \mathrm{g} / \mathrm{g}$ of DM) of the same ${ }^{\mathrm{T} 1} L c$-populations harvested in 2007 (Jonker et al., 2010). 
Table 1. Chemical and in situ fractionation of proteins and carbohydrates, degradation rates, passage rates, and ATP yield

\begin{tabular}{|c|c|c|c|c|c|c|c|}
\hline \multirow[b]{2}{*}{ Trait } & \multicolumn{2}{|r|}{ Chemical analysis $^{1}$} & \multicolumn{2}{|r|}{ In situ ${ }^{2}$} & \multicolumn{3}{|c|}{ DVE/OEB } \\
\hline & $\begin{array}{l}\text { Chemical } \\
\text { fractions }\end{array}$ & Calculation & $\begin{array}{l}\text { In situ } \\
\text { fraction }\end{array}$ & Description & $\begin{array}{l}\mathrm{K}_{\mathrm{d}}^{3} \\
(\% / \mathrm{h})\end{array}$ & $\begin{array}{c}\mathrm{K}_{\mathrm{p}}^{4} \\
(\% / \mathrm{h})\end{array}$ & $\begin{array}{c}\text { ATP } \\
\text { yield }^{5} \\
\left(\mathrm{~mol}^{\mathrm{mog}}\right)\end{array}$ \\
\hline \multicolumn{8}{|c|}{ Carbohydrate fraction (\% of $\mathrm{CHO}$ ) } \\
\hline Soluble & $\mathrm{CA}$ & $\mathrm{CHO}-(\mathrm{CB} 2+\mathrm{CB} 3+\mathrm{CC})$ & $\mathrm{S}_{\mathrm{ESC}}$ & $80 \%$ of ethanol-soluble $\mathrm{CHO}$ & 2.0 & 0.11 & 23.9 \\
\hline Potentially degradable & CB2 & RNSP $^{6}$ & $\mathrm{WI}_{\mathrm{RNSP}}{ }^{6}$ & $\begin{array}{c}100-\left(0 \mathrm{~h} \_\mathrm{ASH}+65 \% \times \mathrm{EE}\right. \\
\left.+0 \mathrm{~h} \_\mathrm{CP}+\mathrm{NDF}+\mathrm{ESC}\right)\end{array}$ & $2.5 \times \mathrm{K}_{\mathrm{dRNSP}}$ & 0.08 & 23.9 \\
\hline Undegradable & $\begin{array}{l}\text { CB3 } \\
\text { CC }\end{array}$ & $\begin{array}{l}\mathrm{NDF}-\mathrm{CC} \\
(\mathrm{NDF} \times(\mathrm{ADL} / \mathrm{NDF}) \\
\times 2.4) / \mathrm{CHO} \times 100\end{array}$ & $\begin{array}{l}\mathrm{D}_{\mathrm{RNSP}}{ }^{6} \\
\mathrm{D}_{\mathrm{NDF}}{ }^{6} \\
\mathrm{U}_{\mathrm{RNSP}}{ }^{6}\end{array}$ & $\begin{array}{l}100-\left(\mathrm{WI}_{\mathrm{RNSP}}+\mathrm{U}_{\mathrm{RNSP}}\right) \\
100-\left(\mathrm{WI}_{\mathrm{NDF}}+\mathrm{U}_{\mathrm{NDF}}\right) \\
100-\left(72 \mathrm{~h} \_\mathrm{ASH}+\mathrm{U}_{\mathrm{CP}}+\mathrm{U}_{\mathrm{NDF}}\right)\end{array}$ & $\begin{array}{c}\mathrm{K}_{\mathrm{dRNSP}} \\
\mathrm{K}_{\mathrm{dNDF}}\end{array}$ & $\begin{array}{c}0.0139+0.1775 \times \mathrm{K}_{\mathrm{dRNSP}} \\
0.0139+0.1775 \times \mathrm{K}_{\mathrm{dNDF}} \\
-\end{array}$ & $\begin{array}{r}27.3 \\
27.3 \\
-\end{array}$ \\
\hline Protein fraction (\% of $\mathrm{CP}$ ) & & & $\mathrm{U}_{\mathrm{NDF}}$ & 72-h residue & - & - & - \\
\hline Soluble & $\mathrm{PA}$ & $\mathrm{NPN}$ & $\mathrm{S}_{\mathrm{CP}}$ & Soluble washable fraction & 2.0 & 0.11 & 13.6 \\
\hline Potentially degradable & $\mathrm{PB}$ & $\mathrm{CP}-(\mathrm{NPN}+\mathrm{ADIP})$ & $\mathrm{WI}_{\mathrm{CP}}$ & Washable $\mathrm{CP}-\mathrm{S}_{\mathrm{CP}}$ & $\mathrm{K}_{\mathrm{dCP}}$ & 0.08 & 13.6 \\
\hline Undegradable & $\mathrm{PC}$ & ADIP & $\begin{array}{l}\mathrm{D}_{\mathrm{CP}} \\
\mathrm{U}_{\mathrm{CP}}\end{array}$ & $\begin{array}{l}100-\left(\mathrm{WI}_{\mathrm{CP}}+\mathrm{U}_{\mathrm{CP}}\right) \\
72 \text {-h residue }\end{array}$ & $\underline{\mathrm{KCP}}$ & $\underline{0.06}$ & $\underline{13.6}$ \\
\hline
\end{tabular}

${ }^{1}$ Carbohydrate (CHO) and CP fractions calculated by the Cornell Net Carbohydrate and Protein System (CNCPS) system based on chemical analysis in \% of CHO and CP, respectively. $\mathrm{CA}=$ soluble $\mathrm{CHO}$; $\mathrm{CB} 2=$ potentially degradable soluble fiber; $\mathrm{CB} 3=$ potentially degradable $\mathrm{NDF} ; \mathrm{CC}=$ undegradable $\mathrm{CHO}$; $\mathrm{PA}=$ soluble $\mathrm{CP}$; $\mathrm{PB}=$ potentially degradable CP; PC = undegradable CP (Sniffen et al., 1992). ADL = acid detergent lignin; ADIP = acid detergent-insoluble protein.

${ }^{2}$ In situ CHO and CP fractions used in the intestinal digestible protein/rumen-degraded protein balance (DVE/OEB) system in \% of CHO and CP, respectively. S = truly soluble washable fraction; WI = washable insoluble fraction; $\mathrm{D}=$ potentially degradable fraction; $\mathrm{U}=$ completely undegraded fraction; $\mathrm{EE}=$ ether extraction. Subscript letters: $\mathrm{ESC}=$ CHO soluble in $80 \%$ of ethanol; RNSP = residual nonstarch polysaccharides (Tamminga et al., 2007).

${ }^{3} K_{d}$, the fractional degradation rate of the D fractions, was calculated by the exponential model of Robinson et al. (1986), whereas $K_{d}$ values for the $\mathrm{S}$ and WI fractions were adapted from Tamminga et al. (2007).

${ }^{4} \mathrm{~K}_{\mathrm{p}}$ is the fractional passage rate; values and equations where adapted from Tamminga et al. (2007).

${ }^{5}$ Energy content (ATP) of each in situ fraction was adapted from Tamminga et al. (2007).

${ }^{6} \mathrm{RNSP}$ content was calculated as $100-$ (ash + EE + CP + NDF + ESC). Correction factors 65, 44, 17, and 3\% of the original EE, as described in Tamminga et al. (2007), were applied to calculate RNSP for the 0-, 2-, 6-, and 12-h incubation residues, respectively. 
Table 2. Protein and energy system equations to calculate intestinal digestible protein (DVE), rumen-degraded protein balance (OEB), and $\mathrm{NE}_{\mathrm{L}}$

\begin{tabular}{|c|c|}
\hline Trait & Calculation \\
\hline $\mathrm{OEB}$ & $\mathrm{MCP}^{\mathrm{RDP}}-\mathrm{MCP}^{\mathrm{FOMr}}$ \\
\hline Rumen-degradable CP ( $\left.\mathrm{RD}_{\mathrm{CP}}\right)$ & {$\left[\mathrm{S}_{\mathrm{CP}} \times \mathrm{K}_{\mathrm{dS}} /\left(\mathrm{K}_{\mathrm{dS}}+\mathrm{K}_{\mathrm{pS}}\right)\right]+\left[\mathrm{D}_{\mathrm{CP}} \times \mathrm{K}_{\mathrm{pD}} /\left(\mathrm{K}_{\mathrm{dD}}+\mathrm{K}_{\mathrm{pD}}\right)\right]^{2}$} \\
\hline Microbial CP from $\mathrm{RD}_{\mathrm{CP}}\left(\mathrm{MCPr}^{\mathrm{RDP}}\right)$ & $\mathrm{RD}_{\mathrm{CP}}$ \\
\hline Rumen-fermentable OM (FOMr) & $\Sigma K_{d} /\left(K_{d}+K_{p}\right) \times$ in situ fractions \\
\hline Microbial CP from FOMr (MCPr $\left.{ }^{\mathrm{FOMr}}\right)$ & $1 / \mathrm{Y}=\left(\mathrm{M} / \mathrm{GR}+1 / \mathrm{Y}_{\max }\right)^{3}$ \\
\hline Intestinal available MCP (DMCP) & $0.85 \times 0.75 \times \mathrm{MCP}^{\mathrm{FOMr} 4}$ \\
\hline Intestinal available RUP (DRUP) & $\mathrm{RU}_{\mathrm{CP}}-\mathrm{U}_{\mathrm{CP}}$ \\
\hline Endogenous fecal CP losses (DMFP) & $0.075 \times[\mathrm{DM}-(\mathrm{tDOM}+\mathrm{DASH})]^{5}$ \\
\hline Total digestible ash (DASH) & $\mathrm{ASH} \times 0.65$ \\
\hline Total digestible OM (tDOM) & $\mathrm{OM}-\mathrm{U}_{\mathrm{OM}}$ \\
\hline \multicolumn{2}{|l|}{ Energy system (KJ/kg of DM) } \\
\hline Gross energy (GE) & Analyzed by Bomb calorimetry \\
\hline
\end{tabular}

${ }^{1}$ Parameters were calculated according to Tamminga et al. (2007).

${ }^{2} \mathrm{~S}_{\mathrm{CP}}=$ truly soluble washable $\mathrm{CP}(\mathrm{g} / \mathrm{kg}$ of $\mathrm{DM}) ; \mathrm{D}_{\mathrm{CP}}=$ potentially degradable $\mathrm{CP}(\mathrm{g} / \mathrm{kg}$ of DM$) ; \mathrm{K}_{\mathrm{d}}=$ fractional degradation rate $(\% / \mathrm{h}) ; \mathrm{K}_{\mathrm{P}}$ $=$ fractional passage rate $(\% / \mathrm{h})$.

${ }^{3} \mathrm{Y}=$ microbial $\mathrm{DM}$ yield; $\mathrm{M}=$ microbial maintenance requirements $(1.365 \mathrm{mmol}$ of $\mathrm{ATP} / \mathrm{g}$ bacteria per $\mathrm{h}$ for the $\mathrm{D}$ fractions, $4.095 \mathrm{mmol}$ of ATP/g of bacteria per $\mathrm{h}$ for the $\mathrm{S}$ and WI fractions); GR = fractional growth rate (affected by ATP yield of specific in situ fractions, $\mathrm{K}_{\mathrm{p}}$, and $\mathrm{M}$ for specific in situ fractions); $\mathrm{Y}_{\max }=$ maximum microbial growth yield (assumed to be $32 \mathrm{~g}$ of microbes/mol of ATP; microbes contain $62.5 \%$ of CP); a correction of 0.20 is applied to adjust the final microbial protein mass for predation by protozoa (Pirt 1965).

${ }^{4}$ The factor 0.85 represents the true protein content of $\mathrm{MCPr}$ and the factor 0.75 represents the digestibility of MCP in the small intestine (Tamminga et al., 1994).

${ }^{5}$ The factor 0.075 assumes that $75 \mathrm{~g}$ of protein is lost in the feces per $1 \mathrm{~kg}$ of undigested DM that passes through the digestive tract (Tamminga et al., 1994).

${ }^{6}$ Metabolizable energy equation adapted from the PDV (2005) website. EE = ether extraction; ESC = carbohydrate soluble in $80 \%$ of ethanol. ${ }^{7}$ Equations adapted from Van Es (1978).

Fiber fraction concentrations, NDF, ADF, and ADL tended $(P<0.10)$ to be higher in AC Grazeland compared with their concentrations in the $3{ }^{\mathrm{T} 1} \mathrm{Lc} c^{1,3,4}$-alfalfa populations ( 59.1 vs. $54.3,53.0$ vs. 47.7 , and 14.6 vs. $11.0 \%$ of CHO, respectively; Table 3 ). Tremblay et al. (2000) screened 27 alfalfa varieties over 2 consecutive years and found that AC Grazeland always had a higher fiber (NDF, ADF) content compared with that of all other varieties tested. This higher fiber content of AC Grazeland likely resulted from its reduced leaf-to-stem ratio and thicker leaf cell walls (Coulman et al., 1998, 2000).

\section{Comparison of In Situ and Chemical Protein Fractionations of ${ }^{T 1}$ LC-Alfalfa and AC Grazeland}

The S protein fractions in both CNCPS and DVE/ OEB systems are presumed to have a fractional degradation rate of $200 \% / h$. Nonprotein N (PA) was similar in all $3{ }^{\mathrm{T} 1} L c$-alfalfa populations and $\mathrm{AC}$ Grazeland (average of $62.9 \%$ of CP; Table 3), as were the soluble $\mathrm{CP}\left(\mathbf{S}_{\mathbf{C P}}\right)$ fractions and the fractional degradation rates $\left(\boldsymbol{K}_{d \mathbf{C P}}\right)$ of potentially degradable $\mathrm{CP}\left(\mathbf{D}_{\mathrm{CP}}\right.$; Table 4$)$.
However, the $\mathrm{S}_{\mathrm{CP}}$ fraction of ${ }^{\mathrm{T} 1} \mathrm{Ram} L c 3$ was numerically lower (approximately $6.7 \%$ ) and the $\mathrm{D}_{\mathrm{CP}}$ and $K_{d \mathrm{CP}}$ of the same population were numerically higher (approximately $8.1 \%$ and approximately $3.1 \% / \mathrm{h}$, respectively) compared with those of the other 3 populations.

The $\mathrm{S}_{\mathrm{CP}}$ mean of $34.9 \%$ of CP for all alfalfas used in this study was similar to values reported by Aufrère et al. (2000) and Elizalde et al. (1999b) for alfalfa harvested at a vegetative stage of growth. However, the NPN value for PA averaged approximately $28 \%$ of CP higher $(P<0.0001)$ than did the in situ $\mathrm{S}_{\mathrm{CP}}$ value. The $\mathrm{S}_{\mathrm{CP}}$ was determined after solubilizing the alfalfa sample in water for $4 \mathrm{~h}$ at room temperature. In contrast, PA was determined after solubilizing the sample in water with TCA for 30 min, after which the $\mathrm{pH}$ was adjusted to 2 and the solution incubated over night at room temperature. Because TCA precipitates peptides larger than 10 AA units long (Licitra et al., 1996), amino acids and small peptides would be present as contaminants in the PA fraction and could explain the high PA value.

Overall, BSP was higher $(P<0.04)$ in ${ }^{\mathrm{T} 1} L c^{1,3,4}$-alfalfa forage compared with that in AC Grazeland forage (72.6 vs. $70.7 \%$ of CP; Table 3 ). When individual popu- 
Table 3. Phytochemical and chemical composition for ${ }^{\mathrm{T} 1} L c$-alfalfa and AC Grazeland (AG)

\begin{tabular}{|c|c|c|c|c|c|c|c|}
\hline Trait & \multicolumn{4}{|c|}{ Population } & \multicolumn{2}{|c|}{ Model } & $\frac{L c \text { vs. } \mathrm{AG}^{1}}{P \text {-value }}$ \\
\hline Anthocyanidin ( $\mu \mathrm{g} / \mathrm{g}$ of $\mathrm{DM})$ & 175.3 & 135.7 & 179.2 & 0.0 & 58.85 & 0.113 & 0.034 \\
\hline Ash $(\%$ of DM $)$ & 12.9 & 12.4 & 13.6 & 13.7 & 1.10 & 0.084 & 0.108 \\
\hline $\mathrm{EE}^{2}(\%$ of $\mathrm{DM})$ & 4.0 & 3.4 & 3.6 & 3.6 & 0.17 & 0.186 & 0.723 \\
\hline $\mathrm{CP}(\%$ of $\mathrm{DM})$ & 28.7 & 28.2 & 29.1 & 27.3 & 2.22 & 0.313 & 0.130 \\
\hline $\mathrm{PB}(\%$ of $\mathrm{CP})$ & 34.7 & 31.9 & 38.5 & 36.7 & 2.11 & 0.290 & 0.544 \\
\hline NDIP (\% of CP) & 4.1 & 3.8 & 3.9 & 4.2 & 1.37 & 0.817 & 0.518 \\
\hline $\mathrm{ADIP}(\%$ of $\mathrm{CP} ; \mathrm{PC})$ & 1.7 & 1.6 & 1.7 & 1.8 & 0.69 & 0.684 & 0.311 \\
\hline $\mathrm{CHO}^{4}(\%$ of $\mathrm{DM})$ & 54.5 & 55.0 & 54.5 & 55.45 & 1.05 & 0.506 & 0.308 \\
\hline \multicolumn{8}{|l|}{ Carbohydrate subfractions ${ }^{5}$} \\
\hline $\mathrm{ESC}(\%$ of $\mathrm{CHO} ; \mathrm{CA} 4)$ & 7.4 & 5.8 & 7.0 & 6.1 & 2.00 & 0.662 & 0.582 \\
\hline
\end{tabular}

${ }^{1} L c$ vs. AC Grazeland (AG) = comparing the mean of 3 transgenic ${ }^{\mathrm{T} 1} L c$-alfalfa populations $\left({ }^{\mathrm{T} 1} \operatorname{Beav} L c 1,{ }^{\mathrm{T} 1} \operatorname{Ramb} L c 3,{ }^{\mathrm{T} 1} \mathrm{Rang} L c 4\right)$ with variety AC Grazeland (selected for a low initial rate of degradation).

${ }^{2}$ Ether extraction.

${ }^{3} \mathrm{NPN}=$ nitrogenous compounds soluble in water and not precipitated by TCA, called PA in the Cornell Net Carbohydrate and Protein System $(\mathrm{CNCPS}) ; \mathrm{BSP}=\mathrm{CP}$ soluble in phosphate buffer; $\mathrm{PB}=$ true potentially degradable protein calculated in $\%$ of $\mathrm{DM}$ as $\mathrm{CP}-(\mathrm{NPN}+\mathrm{ADIP})$; NDIP $=$ neutral detergent-insoluble CP; ADIP = acid detergent-insoluble CP, called PC in CNCPS.

${ }^{4} \mathrm{CHO}=$ total carbohydrate content calculated as DM $-($ ash $+\mathrm{EE}+\mathrm{CP})$.

${ }^{5} \mathrm{ESC}=\mathrm{CHO}$ soluble in $80 \%$ of ethanol, called CA4 in CNCPS; RNSP, residual nonstarch polysaccharides calculated as CHO $-(\mathrm{NDF}+\mathrm{ESC})$, called CB2 in CNCPS; ADL = acid detergent lignin.

lations were considered, a trend toward highest BSP $(P$ $=0.06)$ was observed for ${ }^{\mathrm{T} 1} \mathrm{Beav} L c 1$ and lowest for $\mathrm{AC}$ Grazeland (Table 3). The mean BSP concentration for all 4 alfalfa populations was higher than values reported in other studies, in which values ranged from 38.4 to $41.1 \%$ of CP (Elizalde et al., 1999b; Grabber, 2009). Previously, in Jonker et al. (2010), we proposed that the high BSP in our alfalfa populations might result from harvesting young plant material rather than more mature material due to a ban on flowering imposed by the CFIA. However, mean in situ $\mathrm{S}_{\mathrm{CP}}$ values were similar to other values reported for alfalfa (Elizalde et al., 1999b; Aufrère et al., 2000). Elizalde et al. (1999b) found only slightly higher soluble protein in BSP than in washable $\mathrm{CP}\left(\mathbf{W}_{\mathbf{C P}}\right)$ from in situ analysis (38.9 vs. $36.6 \%$ of $\mathrm{CP}$ ) in alfalfa harvested at several stages of growth. Therefore, BSP gave a reliable estimate of the in situ washable $\mathrm{W}_{\mathrm{CP}}$ fraction in the study of Elizalde et al. (199b). Thus, BSP gives variable results when compared with in situ $\mathrm{W}_{\mathrm{CP}}$.

All 4 alfalfas had similar completely undegradable ADIP fractions with an average of $1.7 \%$ of $\mathrm{CP}$ (Table 3 ). The ADIP values were, on average, $7.4 \%$ of $\mathrm{CP}$ lower $(P<0.0001)$ than the values for undegradable $\mathrm{CP}$ $\left(\mathbf{U}_{\mathbf{C P}}\right)$ with the in situ method. Moreover, $\mathrm{U}_{\mathrm{CP}}$ values were lower $(P<0.05)$ in ${ }^{\mathrm{T} 1} \operatorname{Ramb} L c 3$ and ${ }^{\mathrm{T} 1} \operatorname{Rang} L c 4$ compared with those in AC Grazeland, whereas $\mathrm{U}_{\mathrm{CP}}$ values in ${ }^{\mathrm{T} 1}$ Beav $L c 1$ did not differ from those in the other 3 alfalfa populations (Table 4 ). The higher $\mathrm{U}_{\mathrm{CP}}$ compared with ADIP may be caused by contamination of the 72-h in situ residue with microbial protein or more protein was solubilized during ADF determination of the original alfalfa samples than during the 72-h in situ rumen incubations.

The ADIP values for all alfalfa in our study were lower than previously reported ADIP values for alfalfa harvested at a vegetative stage of growth (2.1 to $4.6 \%$ of $\mathrm{CP}$ ), whereas our in situ undegradable $\mathrm{U}_{\mathrm{CP}}$ fractions were in a similar range (5.6 to $15.6 \%$ of $\mathrm{CP}$ ) as those previously reported (Elizalde et al., 1999b; González et al., 2001; Faría-Mármol et al., 2002; Wang et al., 2006b). Moreover, ADIP values were 1.6 to $10.5 \%$ lower in these studies compared with in situ $\mathrm{U}_{\mathrm{CP}}$ values (Elizalde et al., 1999b; González et al., 2001; FaríaMármol et al., 2002). Therefore, our results confirm those of other studies in which ADIP was lower than the in situ undegradable $\mathrm{U}_{\mathrm{CP}}$ fraction. This implies that ADIP might not be a reliable predictor for undegradable $\mathrm{U}_{\mathrm{CP}}$ in alfalfa as stated previously by Pichard and Van Soest (1977) and Haugen et al. (2006). 
Table 4. In situ protein and energy fractions and ruminal degradation for ${ }^{\mathrm{T} 1} L c$-alfalfa and $\mathrm{AC}$ Grazeland (AG)

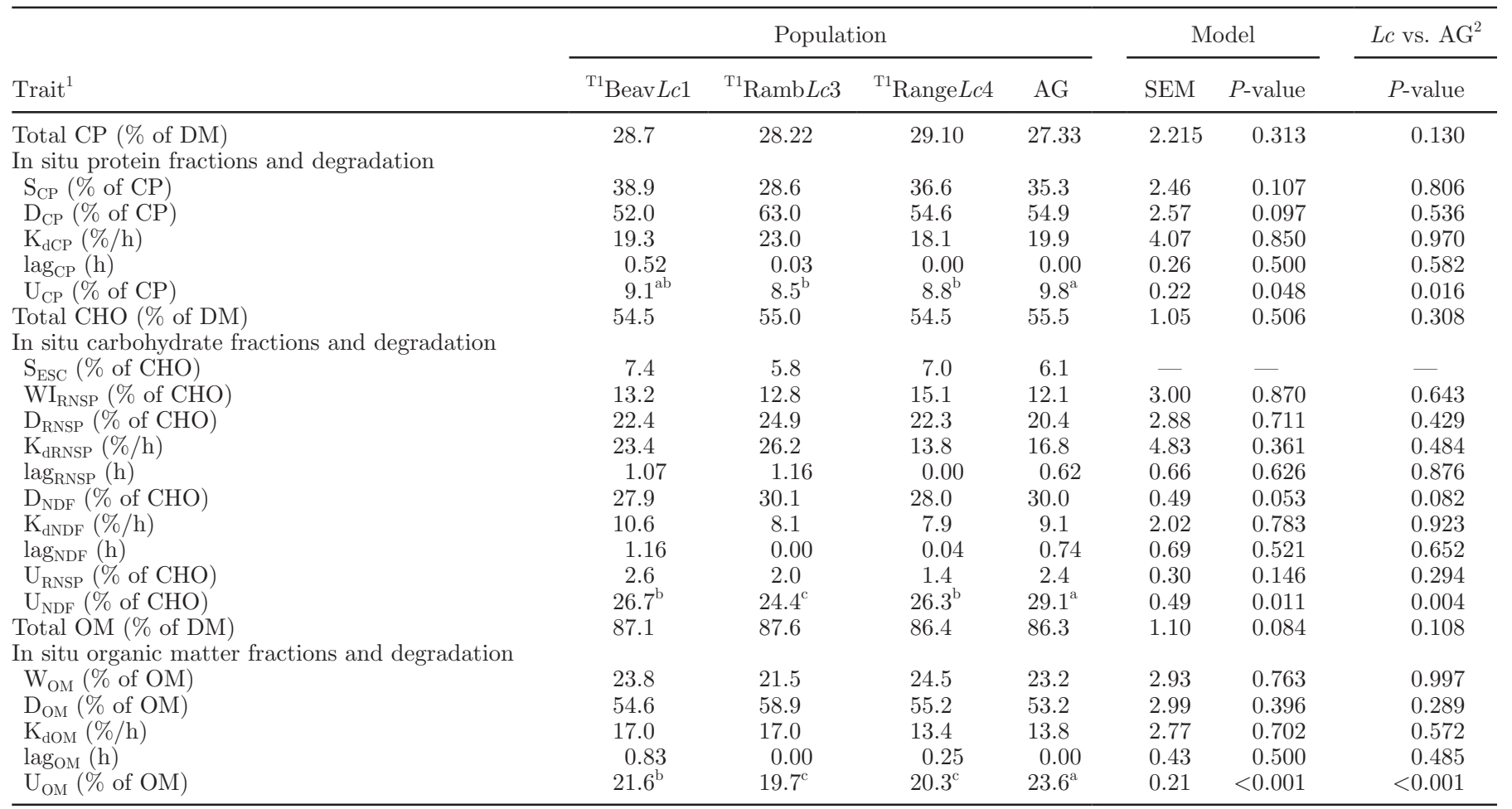

${ }^{\mathrm{a}-\mathrm{c}}$ Means with different supercripts within the same row differ $(P<0.05)$.

${ }^{1} \mathrm{~S}=$ washable soluble fraction; $\mathrm{W}=$ washable fraction; $\mathrm{WI}=$ washable insoluble fraction; $\mathrm{D}=$ potentially degradable fraction calculated as 100 $-(\mathrm{S}+\mathrm{WI}+\mathrm{U}) ; \mathrm{U}=$ undegradable fraction $\left(72\right.$ - $\mathrm{h}$ incubation residue); $\mathrm{CHO}=$ total carbohydrate content; $\mathrm{K}_{\mathrm{d}}=$ fractional degradation rate; lag $=$ lag time before fermentation initiated. Subscript letters: $\mathrm{ESC}=\mathrm{CHO}$ soluble in $80 \%$ of ethanol; RNSP $=$ residual nonstarch polysaccharides. $\mathrm{K}_{\mathrm{d}}$ and lag were calculated by the exponential model of Robinson et al. (1986).

${ }^{2} L c$ vs. AC Grazeland (AG) = comparing the mean of 3 transgenic ${ }^{\mathrm{T} 1} L c$-alfalfa populations $\left({ }^{\mathrm{T} 1} \operatorname{Beav} L c 1,{ }^{\mathrm{T} 1} \operatorname{Ramb} L c 3,{ }^{\mathrm{T} 1} \mathrm{Rang} L c 4\right)$ with variety AC Grazeland (selected for a low initial rate of degradation).

All 4 alfalfa populations in this study had similar potentially degradable true protein $(\mathbf{P B})$ values calculated by the CNCPS system (average $35.5 \%$ of CP; Table 3 ). The potentially degradable $\mathrm{CP}$ fraction $\mathrm{D}_{\mathrm{CP}}$ measured by the in situ method averaged $56.1 \%$ of $\mathrm{CP}$ and was similar for all alfalfas in this study, but a trend was observed for higher $\mathrm{D}_{\mathrm{CP}}(P<0.10)$ in ${ }^{\mathrm{T} 1}$ Ramb $L c 3$ compared with ${ }^{\mathrm{T1}}$ Range $L c 4$ (Table 4 ). The $\mathrm{D}_{\mathrm{CP}}$ values in our study were similar to $\mathrm{D}_{\mathrm{CP}}$ values reported by Aufrère et al. (2000) and Elizalde et al. (1999b) for vegetative alfalfa. The $K_{d \mathrm{CP}}$ for the $\mathrm{D}_{\mathrm{CP}}$ fractions reported in other studies had a fairly large range $(12.2$ to $34.1 \% / \mathrm{h})$ for alfalfa at several stages of growth, whereas the $K_{d \mathrm{CP}}$ for vegetative alfalfa was higher (ranging from 17.9 to $34.1 \% / \mathrm{h}$ ) compared with that for alfalfa forage at more mature stages of growth (Elizalde et al., 1999b; Aufrère et al., 2000; González et al., 2001). The potentially degradable CP (PB) fraction calculated by the CNCPS method was $20.6 \%$ lower $(P$ $<0.0001)$ than the in situ $\mathrm{D}_{\mathrm{CP}}$ fraction by the DVE/ $\mathrm{OEB}^{07}$ system. Potentially degradable PB in our alfalfa germplasm was low, mainly as a result of a high NPN fraction and only a slightly lower ADIP compared with alfalfa tested in other studies where they found higher $\mathrm{PB}$ values (68.7 and $71.7 \%$ of $\mathrm{CP}$, respectively) for alfalfa (Elizalde et al., 1999a; Grabber, 2009). Yu et al. (2003a,b) found PB values (40.7 to $55.5 \%$ of CP) in a similar range to in situ $\mathrm{D}_{\mathrm{CP}}$ values (43.6 to $52.6 \%$ of $\mathrm{CP})$ for alfalfa harvested at different stages of growth. So, in the study of Yu et al. (2003a,b), PB gave a good estimate of $\mathrm{D}_{\mathrm{CP}}$.

\section{Ruminal Protein Availability of ${ }^{T 1}$ Lc-Alfalfa and AC Grazeland}

The DM weight of the alfalfa in situ WI protein fractions was $<0.001 \%$ of DM for all 4 of our alfalfas (data not shown). Azarfar et al. (2007b) and Gierus et al. (2005) found that the WI protein fractions for different concentrates and wet byproduct ingredients lay within a range from 1.9 to $29.3 \%$ of $\mathrm{CP}$, but was minimal (below $1.0 \%$ of CP) for grass silage. The trace levels of WI protein in our trials suggests that freeze-dried alfalfa, similar to grass silage, contains very few small particles 
Table 5. Modeling ruminal and intestinal nutrient availability for ${ }^{\mathrm{T} 1} L c$-alfalfa and AC Grazeland (AG)

\begin{tabular}{|c|c|c|c|c|c|c|c|}
\hline Trait $^{1}$ & \multicolumn{4}{|c|}{ Population } & \multicolumn{2}{|c|}{ Model } & $\frac{L c \text { vs. } \mathrm{AG}^{2}}{P \text {-value }}$ \\
\hline \multicolumn{8}{|l|}{ Ruminal phase } \\
\hline $\mathrm{RD}_{\mathrm{CHO}}(\mathrm{g} / \mathrm{kg}$ of $\mathrm{DM})$ & 313.8 & 325.0 & 305.7 & 302.3 & 5.40 & 0.130 & 0.116 \\
\hline $\mathrm{RD}_{\mathrm{OM}}(\mathrm{g} / \mathrm{kg}$ of $\mathrm{DM})$ & 579.9 & 586.6 & 565.6 & 546.8 & 16.05 & 0.416 & 0.175 \\
\hline FOMr $(\mathrm{g} / \mathrm{kg}$ of $\mathrm{DM})$ & 539.8 & 548.9 & 532.7 & 516.1 & 9.98 & 0.267 & 0.102 \\
\hline \multicolumn{8}{|l|}{ Intestinal phase } \\
\hline $\mathrm{U}_{\mathrm{CP}}(\mathrm{g} / \mathrm{kg}$ of $\mathrm{DM})$ & 26.2 & 23.9 & 25.5 & 26.8 & 0.62 & 0.104 & 0.086 \\
\hline $\mathrm{U}_{\mathrm{DM}}(\mathrm{g} / \mathrm{kg}$ of $\mathrm{DM})$ & $233.5^{\mathrm{b}}$ & $217.4^{\mathrm{c}}$ & $223.1^{\mathrm{c}}$ & $251.5^{\mathrm{a}}$ & 1.78 & $<0.001$ & $<0.001$ \\
\hline DMFP (g/kg of DM) & $17.5^{\mathrm{b}}$ & $16.3^{\mathrm{c}}$ & $16.7^{\mathrm{c}}$ & $18.9^{\mathrm{a}}$ & 0.14 & $<0.001$ & $<0.001$ \\
\hline $\mathrm{RU}_{\mathrm{CP}}(\mathrm{g} / \mathrm{kg}$ of $\mathrm{DM})$ & 60.7 & 58.2 & 64.1 & 59.5 & 4.73 & 0.837 & 0.791 \\
\hline DRUP (g/kg of DM) & 34.5 & 34.3 & 38.6 & 32.7 & 4.72 & 0.836 & 0.594 \\
\hline
\end{tabular}

${ }^{\mathrm{a}-\mathrm{c}}$ Means with different superscripts within the same row differ $(P<0.05)$.

${ }^{1} \mathrm{RD}_{\mathrm{CP}}=$ rumen-degradable protein $; \mathrm{RDOM}=$ rumen-degradable $\mathrm{OM} ; \mathrm{RD}_{\mathrm{CHO}}=$ rumen-degradable carbohydrates; $\mathrm{RD}_{\mathrm{N}}=$ rumen-degradable $\mathrm{N} ;$ $\mathrm{FOMr}=$ rumen-fermentable $\mathrm{OM} ; \mathrm{MCPr}^{\mathrm{FOMr}}=$ ruminal microbial protein synthesis from FOMr; OEB = rumen-degraded protein balance; $\mathrm{U}_{\mathrm{CP}}$ $=$ completely undegradable protein; $\mathrm{U}_{\mathrm{DM}}=$ completely undegradable $\mathrm{DM} ; \mathrm{DMFP}=$ endogenous protein lost into the feces; $\mathrm{RU} \mathrm{CP}_{\mathrm{CP}}=$ rumen-undegradable protein; $\mathrm{DRUP}=$ intestinal available $\mathrm{RU}_{\mathrm{CP}}$; $\mathrm{DMCP}=$ intestinal available microbial protein; DVE = intestinal digestible protein.

${ }^{2} L c$ vs. AC Grazeland $(\mathrm{AG})=$ comparing the mean of 3 transgenic ${ }^{\mathrm{T} 1} L c$-alfalfa populations $\left({ }^{\mathrm{T} 1} \operatorname{Beav} L c 1,{ }^{\mathrm{T} 1} \operatorname{Ramb} L c 3,{ }^{\mathrm{T} 1} \mathrm{Rang} L c 4\right)$ with variety AC Grazeland (selected for a low initial rate of degradation).

that could escape through the pores of the nylon bag during washing.

The rumen-degradable $\mathrm{CP}\left(\mathbf{R D}_{\mathbf{C P}}\right)$ content was similar for each of the 4 alfalfa populations, but a trend toward a higher $\mathrm{RD}_{\mathrm{CP}}$ was found when the mean of ${ }^{\mathrm{T} 1} L c^{1,3,4}$-alfalfa $(P<0.10)$ was compared with that of AC Grazeland (22.6 vs. $21.4 \%$ of DM; Table 5). The mean $\mathrm{RD}_{\mathrm{CP}}$ for all alfalfa populations was, on average, $79.3 \%$ of CP. This was within the range of 71.2 to $89.6 \%$ of CP reported previously for alfalfa harvested at a vegetative stage of growth (Elizalde et al., 1999b; Aufrère et al., 2000; González et al., 2001; Faría-Mármol et al., 2002). Because ADL and other fiber fractions tended to be higher $(P<0.10)$ in AC Grazeland than in ${ }^{\mathrm{T} 1} L c^{1,3,4}$ alfalfa, and increased ADL decreases the digestibility of forages (Jung et al., 1997), the enhanced fiber fractions in AC Grazeland may have had a greater effect on $\mathrm{RD}_{\mathrm{CP}}$ than the anthocyanidin levels in ${ }^{\mathrm{T} 1} L c^{1,3,4}$-alfalfa forage have on protein precipitation.

\section{Comparison of In Situ and Chemical Carbohydrate Fractions of ${ }^{T 1}$ LC-Alfalfa and AC Grazeland}

All in situ-derived CHO fractional degradation rates, lag times, and fractions, except for undegradable fiber $\left(\mathbf{U}_{\mathrm{NDF}}\right)$, were similar $(P>0.05)$ between our 4 alfalfas tested (Table 4$)$. The $\mathrm{U}_{\mathrm{NDF}}$ was higher $(P<$ 0.04) for AC Grazeland compared with that in ${ }^{\mathrm{T} 1} L c^{1,3,4}$ alfalfa (29.1 vs. $25.8 \%$ of $\mathrm{CHO})$. When individual ${ }^{\mathrm{T} 1} \mathrm{Lc}$ populations were assessed, $\mathrm{U}_{\mathrm{NDF}}$ was lower $(P<0.01)$ for ${ }^{\mathrm{T} 1} \mathrm{Ramb} L c 3$ compared with that for ${ }^{\mathrm{T} 1} \mathrm{Beav} L c 1$ and ${ }^{\mathrm{T} 1}$ Rang $L c 4$. In contrast, ${ }^{\mathrm{T} 1} \mathrm{Ramb} L c 3$ and AC Grazeland trended to have higher $(P<0.10)$ in situ potentially degradable fiber $\left(\mathbf{D}_{\text {NDF }}\right)$ compared with that in ${ }^{\mathrm{T1}}$ Bea$\mathrm{v} L c 1$ and ${ }^{\mathrm{T} 1}$ Rang $L c 4$ (Table 4). When the CNCPS system was compared, undegradable fiber $(\mathrm{CC})$ values for all 4 alfalfa populations were consistent with the combined values for undegradable in situ $\mathrm{U}_{\mathrm{NDF}}+$ undegradable in situ RNSP ( $\mathbf{U}_{\text {RNSP }}$ ) fractions from the DVE/OEB system (Table 4). Whereas the trend in AC Grazeland toward higher ADL content $(P<0.08$; Table 3) may have had a negative effect on NDF digestibility (Jung et al., 1997), differences between the $\mathrm{U}_{\mathrm{NDF}}$ and $D_{\mathrm{NDF}}$ for ${ }^{\mathrm{T} 1} \mathrm{Ramb} L c 3$ and the other $2{ }^{\mathrm{T} 1} L c$-alfalfa populations may have resulted from the numerically lower anthocyanidin content in ${ }^{\mathrm{T} 1} \mathrm{Ramb} L c 3$ (Table 3 ).

In the CNCPS system, a fractional degradation rate of $8 \% / \mathrm{h}$ is assumed for potentially degradable NDF (CB3) of alfalfa pasture (Tylutki et al., 2008). In our study, the in situ fractional degradation rate of $\mathrm{D}_{\mathrm{NDF}}$ for all 4 alfalfa populations was similar with an average of $8.9 \% / \mathrm{h}$. Our in situ results were consistent with the value assumed by the CNCPS system, but higher than the range of 4.7 to $7.26 \% / \mathrm{h}$ reported by Yu et al. (2004) for alfalfa harvested at several stages of growth.

In situ-derived potentially degradable RNSP $\left(\mathbf{D}_{\mathrm{RNSP}}\right)$ fractions were similar between the alfalfa populations (Table 4) and were consistent with values reported by 
Yu et al. (2004) for alfalfa. All 4 alfalfa populations had similar RNSP (CB2) fractions $(P>0.05)$, but RNSP was numerically higher for individual ${ }^{\mathrm{T} 1} L c$-alfalfa populations compared with that in AC Grazeland (Table 3). The fractional degradation rate of RNSP $\left(K_{d R N S P}\right)$ for alfalfa forage averaged $20.1 \% / \mathrm{h}$ and was highly variable between the populations. This $K_{d \mathrm{RNSP}}$ in our study was 2 -fold higher than the range (7.83 to $9.48 \% / \mathrm{h}$ ) reported for alfalfa forage by $\mathrm{Yu}$ et al. (2004), but 1.7-fold lower than the $35 \% / \mathrm{h}$ value assumed for alfalfa CB2 fractions in the CNCPS system (Lanzas et al., 2007). Moreover, the CNCPS system has only one RNSP fraction, CB2, whereas in situ methods fractionate RNSP into a washable insoluble fraction ( $\left.\mathbf{W I}_{\mathbf{R N S P}}\right)$ and potentially degradable and undegradable fractions. Because the $\mathrm{WI}_{\mathrm{RNSP}}$ fraction of alfalfa forage is assumed to have a $K_{d}$ of $250 \% / \mathrm{h}$, this would substantially increase the $K_{d}$ of the total RNSP fraction (Tamminga et al., 2007), if the $\mathrm{WI}_{\mathrm{RNSP}}$ fraction formed a major part of the RNSP.

\section{Modeling Ruminal Energy Availability of ${ }^{T 1}$ LC-Alfalfa and AC Grazeland}

Rumen degradable OM ( $\left.\mathbf{R D}_{\mathrm{OM}}\right)$ can be used to predict fermentable OM (FOMr). Using this method, in situ washable OM $\left(\mathbf{W}_{\mathrm{OM}}\right)$, potentially degradable $\mathrm{OM}\left(\mathbf{D}_{\mathrm{OM}}\right)$, fractional degradation rate of $\mathrm{OM}\left(\mathrm{K}_{\mathrm{dOM}}\right)$, and lag time before the initiation of $\mathrm{D}_{\mathrm{OM}}$ fermentation were similar between our 4 alfalfa populations (Table 4 ) and resulted in a similar $\mathrm{RD}_{\mathrm{OM}}$ (Table 5). However, the undegradable $\mathrm{OM}\left(\mathbf{U}_{\mathrm{OM}}\right)$ mean was higher $(P<$ 0.001) in AC Grazeland compared with the mean in ${ }^{\mathrm{T} 1} L c^{1,3,4}$-alfalfa, and $\mathrm{U}_{\mathrm{OM}}$ within the $3{ }^{\mathrm{T} 1} L c$ populations was higher $(P<0.001)$ in ${ }^{\mathrm{Tl}}$ Beav $L c 4$ compared with that in ${ }^{\mathrm{T} 1}$ RambLc3 and ${ }^{\mathrm{T} 1}$ Range Lc4 (Table 4). The mean $\mathrm{RD}_{\mathrm{OM}}$ content of all 4 populations was $58.4 \%$ of DM. This was slightly lower than the range (63.2 to $72.0 \%$ of DM) reported by Yu et al. (2003a) for alfalfa. The higher $\mathrm{RD}_{\mathrm{OM}}$ values for alfalfa reported by $\mathrm{Yu}$ et al. (2003a) were likely the result of a higher $\mathrm{W}_{\mathrm{OM}}$ fraction, a lower $\mathrm{U}_{\mathrm{OM}}$ fraction, and a lower passage rate (4.0 vs. $4.5 \% / \mathrm{h}$ in our study) chosen by Yu et al. (2003a) for the calculation of $\mathrm{RD}_{\mathrm{OM}}$. The larger $\mathrm{W}_{\mathrm{OM}}$ fraction most likely is due to a larger nylon bag pore size used (53 $\mu \mathrm{m})$, which would allow more insoluble feed particles to escape from the bag and would overestimate the $\mathrm{W}_{\mathrm{OM}}$ fraction.

In the 2007 DVE/OEB system, FOMr is calculated as the sum of all rumen-degradable fractions, which was similar for all 4 alfalfa populations with a numerical trend toward lower FOMr in AC Grazeland and a mean FOMr of $53.4 \%$ of DM (Table 5 ). The FOMr was $3.5 \%$ lower $(P<0.001)$ than the $\mathrm{RD}_{\mathrm{OM}}$ (Table 5$)$.
To calculate $\mathrm{RD}_{\mathrm{OM}}$, it is assumed that the washable (S and WI) in situ fractions are completely degraded in the rumen, whereas the calculation FOMr assumes that a portion of the washable in situ fraction escapes ruminal degradation. Because the $\mathrm{W}_{\mathrm{OM}}$ fraction used in the calculation of $\mathrm{RD}_{\mathrm{OM}}$ was approximately $3.0 \%$ higher than the sum of the washable in situ fractions $\left(\mathrm{S}_{\mathrm{CP}}+\mathrm{WI}_{\mathrm{RNSP}}\right)$ used for the calculation of FOMr, ruminal escape of $\mathrm{W}$ cannot fully explain the difference between FOMr and $\mathrm{RD}_{\mathrm{OM}}$ (Table 5). Unlike FOMr, the calculation for $\mathrm{RD}_{\mathrm{OM}}$ does not consider that microbes cannot use EE, which was, on average, $3.7 \%$ of DM (Table 3).

\section{Ruminal Protein:Energy Ratios and Synchronization of ${ }^{T 1}$ LC-Alfalfa and AC Grazeland}

The total rumen-degradable $\mathrm{RD}_{\mathrm{N}}: \mathrm{RD}_{\mathrm{CHO}}$ ratio was lower for ${ }^{\mathrm{T1}} \mathrm{Ramb} L c 3$ compared with that of ${ }^{\mathrm{T} 1} \mathrm{Beav} L c 1$ $(P<0.01)$, which in turn, had a lower $\mathrm{RD}_{\mathrm{N}}: \mathrm{RD}_{\mathrm{CHO}}$ ratio than did ${ }^{\mathrm{T} 1} \operatorname{Rang} L c 4$, which had the highest ratio $(P<0.01 ;$ Table 5$)$. A trend existed toward ${ }^{\mathrm{T1}}$ RambLc3 and AC Grazeland having a lower $(P<0.10)$ OEB (balance between MCPr calculated based on protein and energy) compared with that of ${ }^{\mathrm{T} 1}$ Range $L c 4$ and ${ }^{\mathrm{T} 1}$ Beav $L c 1$ (Table 5). The $\mathrm{RD}_{\mathrm{N}}: \mathrm{RD}_{\mathrm{CHO}}$ ratios in this study ranged from 110 to $119 \mathrm{~g} / \mathrm{kg}$ and were 3.5 -fold higher than the $32 \mathrm{~g} / \mathrm{kg}$ required for optimal microbial protein synthesis (Tamminga et al., 1990; Sinclair et al., 1991) and the OEB in this study ranged from 136 to $149 \mathrm{~g} / \mathrm{kg}$, which is much higher than the optimum of zero required for efficient utilization of ruminal $\mathrm{N}$ (Tamminga et al., 1994, 2007).

When our $3{ }^{\mathrm{T} 1} L c$-alfalfa populations and AC Grazeland were evaluated for hourly $\mathrm{RD}_{\mathrm{N}}: \mathrm{RD}_{\mathrm{CHO}}$, a biphasic profile was observed for all 4 types of germplasm and included an initial and substantial peak (oversupply) of $\mathrm{N}$ relative to energy within the first $2 \mathrm{~h}$ after feeding, followed by a slow decline from 2 to $24 \mathrm{~h}$ after feeding (Figure 1A). This latter time period shows a relatively synchronized and balanced ratio when the hourly OEB method is evaluated (Figure 1B). The OEB after $1 \mathrm{~h}$ was least synchronized $(P<0.01)$ for ${ }^{\mathrm{T} 1}$ Beav $L c 1$ and ${ }^{\mathrm{T} 1}$ Rang $L c 4$, followed by AC Grazeland and ${ }^{\mathrm{T} 1} \mathrm{Ramb} L c 3$, after which the OEB between 2 to $24 \mathrm{~h}$ was similar for all 4 alfalfa populations. The more synchronized OEB for ${ }^{\mathrm{T} 1} \mathrm{Ramb} L c 3$ was likely due to a numerically lower highly degradable $\mathrm{S}_{\mathrm{CP}}$ fraction compared with that in the other 3 populations (the $\mathrm{S}_{\mathrm{CP}}$ fraction is almost completely gone after $1 \mathrm{~h}$ ). The hourly rumen-degradable $R D_{\mathrm{N}}: \mathrm{RD}_{\mathrm{CHO}}$ ratio of perennial ryegrass, which is characterized by a high soluble protein content and high initial rate of degradation as alfalfa, follows a similar 

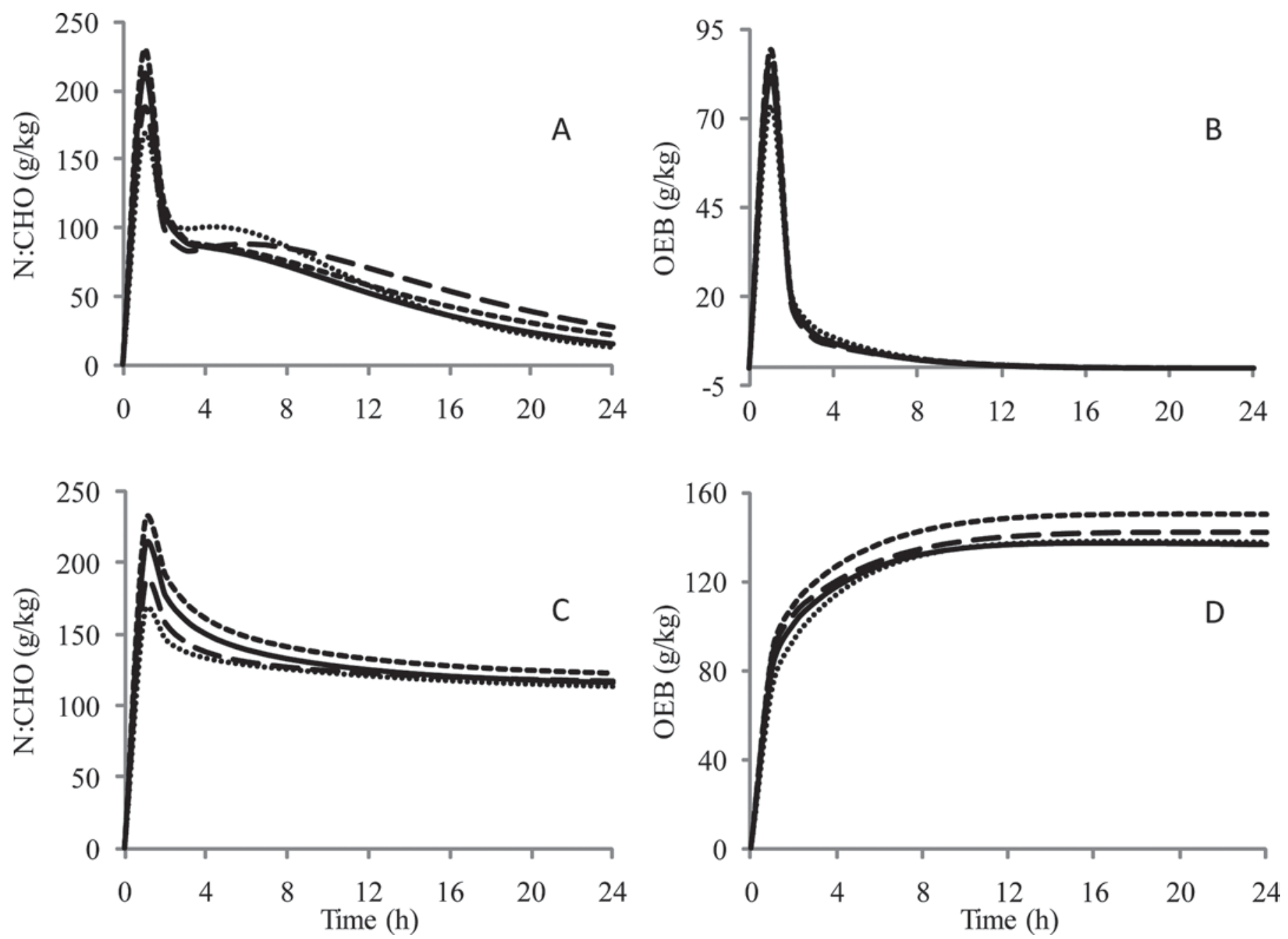

Figure 1. Degradation ratios of alfalfa populations ${ }^{\mathrm{T} 1} \operatorname{Beav} L c 1(---),{ }^{\mathrm{T} 1} \operatorname{Ramb} L c 3(\cdots \cdots),{ }^{\mathrm{T} 1} \operatorname{Rang} L c 4(----)$, and $\mathrm{AC}$ Grazeland $\left.\left(-\frac{\mathrm{C}}{\mathrm{C}}\right) . \mathrm{A}\right)$ Hourly ratio of rumen-degradable N-to-carbohydrate ratio (N:CHO); B) hourly rumen-degraded protein balance (OEB); C) cumulative rumendegradable N:CHO; D) cumulative OEB.

pattern (Tas et al., 2006), but the magnitude of imbalance for alfalfa was much higher than for perennial ryegrass.

Excessive protein supplied, above microbial requirements, from alfalfa within the first $2 \mathrm{~h}$ of ruminant ingestion will mainly be deaminated into $\mathrm{NH}_{3}$ by rumen microbes, then absorbed by the rumen wall and converted into urea in the liver at the cost of energy (van Duinkerken et al., 2005). Urea-N can re-enter the rumen via secreted saliva or direct diffusion into the rumen, where it is converted back into $\mathrm{NH}_{3}$. When sufficient energy is available, $\mathrm{NH}_{3}$ can be used for microbial protein synthesis; otherwise, $\mathrm{NH}_{3}$ will be mainly lost to the animal and excreted via urea in the urine (Lapierre and Lobley, 2001). Valkeners et al. (2004) found that an unsynchronized N-to-energy supply during parts of the day can be balanced by urea- $\mathrm{N}$ recycling when the overall N-to-energy supply is balanced on a daily basis.
However, the cumulative protein and energy synchronization shown in Figure 1C and D suggests that urea recycling will be ineffective for the 4 alfalfa populations, with $\mathrm{AC}$ Grazeland and ${ }^{\mathrm{T1}} \mathrm{Ramb} L c 3$ being more effective than ${ }^{\mathrm{T} 1}$ Beav $L c 1$ and ${ }^{\mathrm{T} 1}$ Rang $L c 4$. These data are consistent with other research showing that alfalfa requires decreased ruminal protein release or additional ruminal energy inputs (Yu et al., 2003a). One should also note that cows graze in 3 main grazing bouts per day (Gibb et al., 1998; Taweel et al., 2004). Therefore, in a 24 -h period, the excessively high protein supply within the first $2 \mathrm{~h}$ after ingestion will occur at least 3 times per day.

\section{Modeling Intestinally Available Protein of ${ }^{T 1}$ LC-Alfalfa and AC Grazeland}

The predicted microbial protein synthesis in the rumen $(\mathrm{MCPr})$ and, therefore, predicted intestinally avail- 


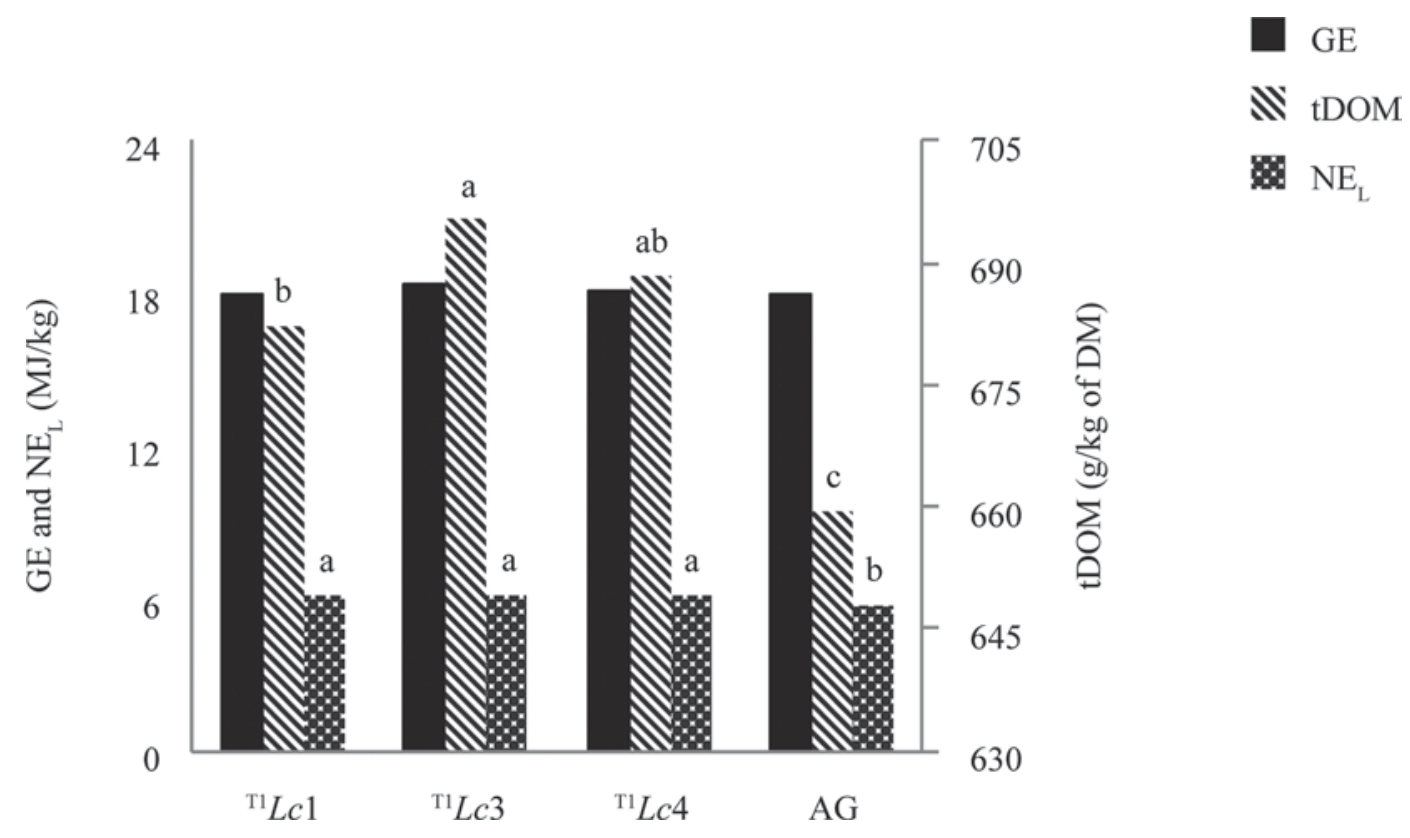

Figure 2. Energy content of alfalfa populations ${ }^{\mathrm{T} 1} \mathrm{Beav} L c 1,{ }^{\mathrm{T} 1} \operatorname{Ramb} L c 3,{ }^{\mathrm{T} 1} \operatorname{Rang} L c 4$, and $\mathrm{AC}$ Grazeland (AG) as calculated according to Van Es (1978). GE = gross energy (solid bars); tDOM = total-tract digestible OM (striped bars); $\mathrm{NE}_{\mathrm{L}}=$ net energy for lactation (dotted bars). Bars with different letters $(\mathrm{a}-\mathrm{c})$ within the same component differ $(P<0.05)$.

able MCP (DMCP) was similar between the 4 alfalfa populations (Table 5). Because rumen undegradable CP $\left(\mathrm{RU}_{\mathrm{CP}}\right)$ was similar between the 4 alfalfa populations, predicted intestinally available $\mathrm{RU}_{\mathrm{CP}}$ (DRUP) was also similar between the 4 alfalfa populations (Table $5)$. Completely undegradable $\mathrm{DM}\left(\mathrm{U}_{\mathrm{DM}}\right)$ and predicted endogenous protein loss in the feces (DMFP) each were higher $(P<0.001)$ for AC Grazeland compared with the mean of the 3 transgenic ${ }^{\mathrm{T} 1} L c^{1,3,4}$-alfalfa populations (Table 5). When individual populations were considered, both $\mathrm{U}_{\mathrm{DM}}$ and predicted DMFP were higher $(P<0.001)$ for ${ }^{\mathrm{T} 1}$ Beav $L c 1$ than for ${ }^{\mathrm{T1}} \mathrm{Ramb} L c 3$ and ${ }^{\mathrm{T} 1}$ Rang $L c 4$. A trend existed toward a higher predicted intestinally available protein DVE $(P<0.10)$ when the mean of ${ }^{\mathrm{T} 1} L c^{1,3,4}$-alfalfa was compared with that of AC Grazeland (7.2 vs. $6.4 \%$ of DM). The calculated parameters DMCP, DRUP, DMFP, and DVE in our study were similar to values from alfalfa reported by Yu et al. (2003a).

\section{Total Tract Energy Availability of ${ }^{T 1}$ Lc-Alfalfa and AC Grazeland}

Gross energy was similar between the 4 alfalfa populations and total digestible OM (tDOM) was highest for ${ }^{\mathrm{T} 1} \mathrm{Ramb} L c 3$ and ${ }^{\mathrm{T1}} \mathrm{Rang} L c 4$, followed by ${ }^{\mathrm{T} 1}$ Beav $L c 1$, and lowest for AC Grazeland $(P<0.001$; Figure 2). The higher tDOM resulted in a higher $(P<0.001)$ predicted $\mathrm{NE}_{\mathrm{L}}$ for the mean of the $3{ }^{\mathrm{T} 1} L c^{1,3,4}$-alfalfa populations compared with that of AC Grazeland (6.2 vs. $5.8 \mathrm{MJ} / \mathrm{kg}$ ). These predicted $\mathrm{NE}_{\mathrm{L}}$ values were much higher than the $\mathrm{NE}_{\mathrm{L}}$ value of $5.1 \mathrm{MJ} / \mathrm{kg}$ reported in the CVB (2005) feed tables for fresh alfalfa. However, the feed tables do not describe the stage of growth at alfalfa harvest.

\section{Calculated Milk Production of ${ }^{T 1}$ Lc-Alfalfa and AC Grazeland}

The higher predicted $\mathrm{NE}_{\mathrm{L}}$ for the $3{ }^{\mathrm{T} 1} L c^{1,3,4}$-alfalfa populations (Figure 2) resulted in a higher calculated FPCM based on $\mathrm{NE}_{\mathrm{L}}$ (FPCM_NE $)$ for these populations compared with that for AC Grazeland (16.5 vs. $14.9 \mathrm{~kg}$; Figure 3). Because of the trend toward higher predicted DVE, when the mean of the $3{ }^{\mathrm{T} 1} L c^{1,3,4}$ alfalfa populations was compared with that of AC Grazeland, a trend toward higher $(P<0.10)$ calculated FPCM based on DVE (FPCM_DVE) also was observed in ${ }^{\mathrm{T} 1} L c^{1,3,4}$-alfalfa $(19.1$ vs. $16.7 \mathrm{~kg} / \mathrm{d})$. The $\mathrm{FPCM}$ calculated based on $\mathrm{NE}_{\mathrm{L}}$ was, on average, $2.4 \mathrm{~kg} / \mathrm{d}$ lower than the FPCM based on DVE. This means that for a 650-kg Holstein-Friesian cow with a DMI of $15 \mathrm{~kg} / \mathrm{d}$, $\mathrm{NE}_{\mathrm{L}}$ intake would be the first limiting factor for milk production using the alfalfas in this study.

Castillo et al. (2006) did a survey on 8 dairy farms that graze their dairy cattle on alfalfa pasture. They found an average milk production of $15.1 \mathrm{~kg}$ of milk for dairy cows with an average DMI of $15 \mathrm{~kg} / \mathrm{d}$ (Castillo 


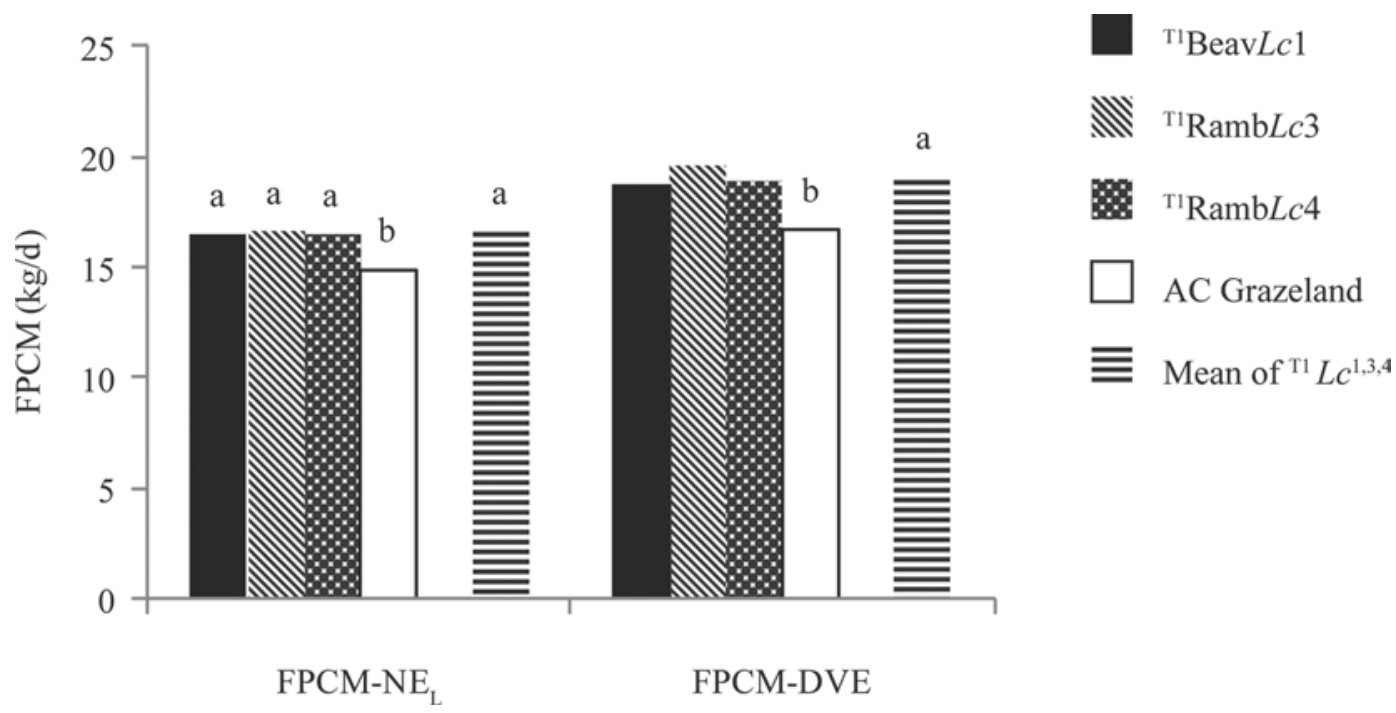

Figure 3. Fat/protein-corrected milk production (FPCM) from $\mathrm{NE}_{\mathrm{L}}$ and intestinal digestible protein (DVE) calculated according to CVB (2005) for a Holstein-Friesian cow of $650 \mathrm{~kg}$ with a DMI of $15 \mathrm{~kg} / \mathrm{d}$ from alfalfa populations ${ }^{\mathrm{T} 1}$ Beav $L c 1$ (solid bars), ${ }^{\mathrm{T} 1} \mathrm{Ramb} L c 3$ (diagonally striped bars), ${ }^{\mathrm{T} 1} \operatorname{Rang} L c 4$ (dotted bars), AC Grazeland (open bars), and the mean of the $3{ }^{\mathrm{T} 1} L c^{1,3,4}$-alfalfas (horizontally striped bars). Bars of FPCM-NE $\mathrm{L}_{\mathrm{L}}$ with different letters $(\mathrm{a}, \mathrm{b})$ differ $(P<0.05)$; bars of the mean ${ }^{\mathrm{T} 1} L c^{1,3,4}$-alfalfa and AC Grazeland for FCPM-DVE differ $(P<$ $0.10)$.

et al., 2006). Their in vivo results are similar to the calculated results we found using modeling methods.

\section{Application}

The trend toward a higher predicted DVE and a higher predicted $\mathrm{NE}_{\mathrm{L}}$ in the $3{ }^{\mathrm{T} 1} L c$-alfalfa populations resulted in a higher calculated milk production compared with that of AC Grazeland. However, differences between the ${ }^{\mathrm{T} 1} L c$-alfalfa and AC Grazeland were modest and were not the result of a shift in the site of nutrient degradation. Therefore, more substantial modifications to increase mono/polymeric anthocyanidin accumulation over the levels present in ${ }^{\mathrm{T} 1} L c$-alfalfa are needed to develop an alfalfa variety with superior nutritional characteristics compared with currently available alfalfa varieties. Such modifications could include the development of $L c$-alfalfa plants with multiple copies of the $L c$ transgene or introduction of additional regulatory genes that promote mono/polymeric anthocyanidin accumulation. Such genes could include the maize $C 1 M Y B$ regulatory gene (which is a partner to $L c$; Paz-Arez et al., 1987), other WD40 partner proteins (Pang et al., 2009), and the Medicago truncatula LAP1 MYB regulatory gene (Peel et al., 2009). Additional basic research to clearly define the final condensation and vacuolar uptake steps of polymeric anthocyanidin biosynthesis and to find new regulatory genes would also shed light on additional genes that may be useful to support the development of polymeric anthocyanidin-accumulating alfalfa. These developments depend on new functional genomics strategies in Medicago truncatula (Pang et al., 2007) and the discovery of new transparent testa mutants in Arabidopsis (Robinson et al., 2009).

\section{CONCLUSIONS}

Forage nutritional characteristics were predicted using the CNCPS system, the 2007 DVE/OEB protein system and VEM energy system to compare ${ }^{\mathrm{T} 1} L c$-alfalfa populations with raised forage anthocyanidins with the variety AC Grazeland, which had been selected earlier for a lower initial rate of degradation. The ${ }^{\mathrm{T} 1} L c$-transgenic populations had an average forage anthocyanidin concentration of $163.4 \mu \mathrm{g} / \mathrm{g}$ of DM, whereas AC Grazeland did not accumulate anthocyanidin. Crude protein, NDF, and residual nonstarch polysaccharide content were similar in the forage of the $3{ }^{\mathrm{T} 1} L c$-alfalfa populations and AC Grazeland. AC Grazeland had higher undegradable in situ $\mathrm{CP}$ and NDF content compared with that of the ${ }^{\mathrm{T} 1} L c$-alfalfa populations, and a trend toward higher predicted rumen degradable protein content, rumen OEB and DVE content for ${ }^{\mathrm{T} 1} L c$-alfalfa was noted. When comparing individual ${ }^{\mathrm{T} 1} L c$-alfalfa populations, ${ }^{\mathrm{T} 1}$ Ramb $L c 3$ had numerically the lowest soluble and undegradable and highest potentially degradable in situ protein and CHO fractions of all of the ${ }^{\mathrm{T} 1} L c$-alfalfa populations, which resulted in a numerically lower predicted rumen OEB and numerically higher predicted 
DVE in ${ }^{\mathrm{T} 1}$ RambLc3. The hourly rumen OEB synchronization differed only after $1 \mathrm{~h}$ for the 4 populations, and the $\mathrm{NE}_{\mathrm{L}}$ was higher in ${ }^{\mathrm{T} 1} L c$-alfalfa compared with that for AC Grazeland.

\section{ACKNOWLEDGMENTS}

The authors thank Z. Niu (University of Saskatchewan, Canada), A. Schindelka, J. Holowachuk, and M. $\mathrm{Yu}$ (Agriculture and Agri-Food Canada, Saskatoon) for assistance with the laboratory, animal, and field work. Project funding from the Agricultural Development Fund from the Government of Saskatchewan is gratefully acknowledged.

\section{REFERENCES}

Aerts, R. J., T. N. Barry, and W. C. McNabb. 1999. Polyphenols and agriculture: Beneficial effects of proanthocyanidins in forages. Agric. Ecosyst. Environ. 75:1-12.

AOAC. 1990. Official Methods of Analysis. 15th ed. Association of Official Analytical Chemists, Arlington, VA.

Aufrère, J., D. Graviou, R. Baumont, A. Detour, and C. Demarquilly. 2000. Degradation in the rumen of proteins from fresh lucerne forage in various stages of growth and conserved as silage or hay. Ann. Zootech. 49:461-474.

Azarfar, A., S. Tamminga, and H. Boer. 2007a. Effects of washing procedure, particle size and dilution on the distribution between non-washable, insoluble washable and soluble washable fractions in concentrate ingredients. J. Sci. Food Agric. 87:2390-2398.

Azarfar, A., B. A. Williams, H. Boer, and S. Tamminga. 2007b. In vitro gas production profile and the formation of end products from non-washable, insoluble washable and soluble washable fractions in some concentrate ingredients. J. Sci. Food Agric. 87:1345-1355.

Barry, T. N. 1981. Protein metabolism in growing lambs fed on fresh ryegrass (Lolium perenne) clover (Trifolium repens) pasture ad lib. 1. Protein and energy deposition in response to abomasal infusion of casein and methionine. Br. J. Nutr. 46:521-532.

Bermingham, E. N., K. J. Hutchinson, D. K. Revell, I. M. Brookes, and W. C. McNabb. 2001. The effect of condensed tannins in sainfoin (Onobrychis viciifolia) and sulla (Hedysarum coronarium) on the digestion of amino acids in sheep. Proc. N. Z. Soc. Anim. Prod. 61:116-119.

Bouton, J. 2008. Biotechnology delivers better alfalfa. National Alfalfa Symposium, February 4-5. Kearney, NE. Hay \& Forage Growers.

Broderick, G. A. 1995. Desirable characteristics of forage legumes for improving protein utilization in ruminants. J. Anim. Sci. 73:2760-2773.

Castillo, A. R., M. A. Taverna, R. R. Páez, A. Cuatrin, D. Colombatto, F. Bargo, M. S. García, P. T. García, M. Chavez, A. D. Beaulieu, and J. K. Drackley. 2006. Fatty acid composition of milk from dairy cows fed fresh alfalfa based diets. Anim. Feed Sci. Technol. 131:241-254.

CCAC. 1993. Guide to the Care and Use of Experimental Animals. Vol. 1. 2nd ed. Canadian Council on Animal Care, Ottawa, Canada.

Coulman, B., C. Duncan, and B. P. Goplen. 1998. Response to four cycles of selection for low initial rate of digestion in alfalfa. Pages 59-60 in 36th North American Alfalfa Improvement Conference (NAAIC), Bozeman, M.

Coulman, B., B. Goplen, W. Majak, T. A. McAllister, K. J. Cheng, B. Berg, J. W. Hall, D. McCartney, and S. N. Acharya. 2000. A review of the development of a bloat-reduced alfalfa cultivar. Can. J. Plant Sci. 80:487-491.

CVB. 2005. Centraal Veevoeder Bureau: Tabellenboek Veevoeding (Dutch Feed Table's Booklet). CVB, Lelystad, the Netherlands.
Dhiman, T. R., and L. D. Satter. 1993. Protein as the first-limiting nutrient for lactating dairy cows fed high proportions of good quality alfalfa silage. J. Dairy Sci. 76:1960-1971.

Elizalde, J. C., N. R. Merchen, and D. B. Faulkner. 1999a. Fractionation of fiber and crude protein in fresh forages during the spring growth. J. Anim. Sci. 77:476-484.

Elizalde, J. C., N. R. Merchen, and D. B. Faulkner. 1999b. In situ dry matter and crude protein degradation of fresh forages during the spring growth. J. Dairy Sci. 82:1978-1990.

Faría-Mármol, J., J. González, C. A. Rodríguez, and M. R. Alvir. 2002. Effect of diet forage to concentrate ratio on rumen degradability and post-ruminal availability of protein from fresh and dried lucerne. Anim. Sci. 74:337-345.

Gibb, M. J., C. A. Huckle, and R. Nuthall. 1998. Effect of time of day on grazing behaviour by lactating dairy cows. Grass Forage Sci. 53:41-46.

Gierus, M., L. de Jonge, and G. A. L. Meijer. 2005. Physico-chemical characteristics and degradation rate of soluble protein obtained from the washout fraction of feeds. Livest. Prod. Sci. 97:219 229

González, J., J. Faría-Mármol, C. A. Rodriguez, and M. R. Alvir. 2001. Effects of stage of harvest on the protein value of fresh lucerne for ruminants. Reprod. Nutr. Dev. 41:381-392.

Goplen, B. P., R. E. Howarth, S. K. Sarkar, and K. Lesins. 1980. A search for condensed tannins in annual and perennial species of Medicago, Trigonella, and Onobrychis. Crop Sci. 20:801-804.

Grabber, J. H. 2009. Protein fractions in forage legumes containing protein-binding polyphenols: Freeze-drying vs. conservation as hay or silage. Anim. Feed Sci. Technol. 151:324-329.

Hall, M. B., W. H. Hoover, J. P. Jennings, and T. K. Miller Webster. 1999. A method for partitioning neutral detergent-soluble carbohydrates. J. Sci. Food Agric. 79:2079-2086.

Haugen, H. L., S. K. Ivan, J. C. MacDonald, and T. J. Klopfenstein. 2006. Determination of undegradable intake protein digestibility of forages using the mobile nylon bag technique. J. Anim. Sci. 84:886-893.

Howarth, R. E. 1975. A review of bloat in cattle. Can. Vet. J. 16:281294.

Jonker, A., M. Y. Gruber, M. McCaslin, Y. Wang, B. Coulman, J. J. McKinnon, D. A. Christensen, and P. Yu. 2010. Nutrient composition and degradation profiles of anthocyanidin-accumulating $L c-$ alfalfa populations. Can. J. Anim. Sci. 90:401-412.

Jung, H. G., D. R. Mertens, and A. J. Payne. 1997. Correlation of acid detergent lignin and Klason lignin with digestibility of forage dry matter and neutral detergent fiber. J. Dairy Sci. 80:1622-1628.

Klopfenstein, T. 1996. Need for escape protein by grazing cattle. Anim. Feed Sci. Technol. 60:191-199.

Lanzas, C., C. J. Sniffen, S. Seo, L. O. Tedeschi, and D. G. Fox. 2007. A revised CNCPS feed carbohydrate fractionation scheme for formulating rations for ruminants. Anim. Feed Sci. Technol. 136:167-190.

Lapierre, H., and G. E. Lobley. 2001. Nitrogen recycling in the ruminant: A review. J. Dairy Sci. 84(E-Suppl):E223-E236.

Licitra, G., T. M. Hernandez, and P. J. Van Soest. 1996. Standardization of procedures for nitrogen fractionation of ruminant feeds. Anim. Feed Sci. Technol. 57:347-358.

McMahon, L. R., T. A. McAllister, B. P. Berg, W. Majak, S. N Acharya, J. D. Popp, B. E. Coulman, Y. Wang, and K. J. Cheng. 2000. A review of the effects of forage condensed tannins on ruminal fermentation and bloat in grazing cattle. Can. J. Plant Sci. 80:469-485.

NRC. 2001. National Research Council. Nutrient Requirements of Dairy Cattle. 7th revised ed. National Academy Press, Washington, DC.

Pang, Y., G. J. Peel, E. Wright, Z. Wang, and R. A. Dixon. 2007. Early steps in proanthocyanidin biosynthesis in the model legume Medicago truncatula. Plant Physiol. 145:601-615.

Pang, Y., J. P. Wenger, K. Saathoff, G. J. Peel, J. Wen, D. Huhman, S. N. Allen, Y. Tang, X. Cheng, M. Tadege, P. Ratet, K. S. Mysore, L. W. Sumner, M. D. Marks, and R. A. Dixon. 2009. A WD40 repeat protein from Medicago truncatula is necessary for tissue- 
specific anthocyanin and proanthocyanidin biosynthesis but not for trichome development. Plant Physiol. 151:1114-1129.

Paz-Ares, J., D. Ghosal, U. Wienand, P. A. Peterson, and H. Saedler. 1987. The regulatory C1 locus of Zea mays encodes a protein with homology to $m y b$ proto-oncogene products and with structural similarities to transcriptional activators. EMBO J. 6:3553-3558.

Productschap Diervoeder (PDV). 2005. Productschap Dier Voeding. Actualisatie van de VEM- en VEVI waardering van ruwvoeders (update of VEM and VEVI herbage energy equations). http:// www.pdv.nl/nederland/Voederwaardering/page2136.php.

Peel, G. J., Y. Pang, L. V. Modolo, and R. A. Dixon. 2009. The LAP1 $M Y B$ transcription factor orchestrates anthocyanidin biosynthesis and glycosylation in Medicago. Plant J. 59:136-149.

Pichard, G., and P. J. Van Soest. 1977. Protein solubility of ruminant feeds. Pages 91-98 in Proc. Cornell Nutr. Conf., Ithaca, NY.

Pirt, S. J. 1965. The maintenance energy of bacteria in growing cultures. Proc. R. Soc. Lond. B Biol. Sci. 163:224-231.

Ray, H., M. Yu, P. Auser, L. Blahut-Beatty, B. McKersie, S. Bowley, N. Westcott, B. Coulman, A. Lloyd, and M. Y. Gruber. 2003. Expression of anthocyanins and proanthocyanidins after transformation of alfalfa with maize Lc. Plant Physiol. 132:1448-1463.

Robinson, P. H., J. G. Fadel, and S. Tamminga. 1986. Evaluation of mathematical models to describe neutral detergent residue in terms of its susceptibility to degradation in the rumen. Anim. Feed Sci. Technol. 15:249-271.

Robinson, S. J., L. H. Tang, B. A. G. Mooney, S. J. McKay, W. E. Clarke, M. G. Links, S. Karcz, S. Regan, Y.-Y. Wu, M. Y. Gruber, D. Cui, M. Yu, and I. A. P. Parkin. 2009. An archived activation tagged population of Arabidopsis thaliana to facilitate forward genetics approaches. BMC Plant Biol. 9:101-116.

Rotz, C. A. 1996. Economics of grazing alfalfa on Michigan dairy farms. Pages 72-81 in 26th National Alfalfa Symposium, East Lansing, MI.

SAS. 2003. User's Guide: Statistics. Version 9.2. SAS Institute Inc., Cary, NC.

Saxton, A. M. 1998. A macro for converting mean separation output to letter groupings in Proc Mixed. Pages 1243-1246 in Proc. 23rd SAS User Group Intl. SAS Institute, Cary, NC.

Sinclair, L. A., H. Galbraith, and J. R. Scaife. 1991. Effect of dietary protein concentration and cimaterol on growth and body composition of entire male lambs. Anim. Feed Sci. Technol. 34:181-192.

Sniffen, C. J., J. D. O'Connor, P. J. Van Soest, D. G. Fox, and J. B. Russell. 1992. A net carbohydrate and protein system for evaluating cattle diets: II. Carbohydrate and protein availability. J. Anim. Sci. 70:3562-3577.

Stafford, H. A. 1990. Flavonoid Metabolism. CRC Press, Boca Raton, FL.

Tamminga, S., G. G. Brandsma, J. Dijkstra, G. Van Duinkerken, A. M. Van Vuuren, and M. C. Blok. 2007. Protein evaluation for ruminants: The DVE/OEB 2007 system. CVB documentation report 53. Centraal Veevoeder Bureau, Lelystad, the Netherlands.

Tamminga, S., W. M. Van Straalen, A. P. J. Subnel, R. G. M. Meijer, A. Steg, C. J. G. Wever, and M. C. Blok. 1994. The Dutch protein evaluation system: The DVE/OEB-system. Livest. Prod. Sci. 40:139-155.

Tamminga, S., A. M. van Vuuren, C. J. van der Koelen, R. S. Ketelaar, and P. L. van der Togt. 1990. Ruminal behaviour of structural carbohydrates, non-structural carbohydrates and crude protein from concentrate ingredients in dairy cows. Neth. J. Agric. Sci. $38: 513-526$.
Tas, B. M., H. Z. Taweel, H. J. Smit, A. Elgersma, J. Dijkstra, and S Tamminga. 2006. Rumen degradation characteristics of perennial ryegrass cultivars during the growing season. Anim. Feed Sci. Technol. 131:103-120.

Taweel, H. Z., B. M. Tas, J. Dijkstra, and S. Tamminga. 2004. Intake regulation and grazing behavior of dairy cows under continuous stocking. J. Dairy Sci. 87:3417-3427.

Tremblay, G. F., R. Michaud, G. Bélanger, K. B. McRae, and H. V. Petit. 2000. In vitro ruminal undegradable proteins of alfalfa cultivars. Can. J. Plant Sci. 80:315-325.

Tylutki, T. P., D. G. Fox, V. M. Durbal, L. O. Tedeschi, J. B. Russell, M. E. Van Amburgh, T. R. Overton, L. E. Chase, and A. N. Pell. 2008. Cornell Net Carbohydrate and Protein System: A model for precision feeding of dairy cattle. Anim. Feed Sci. Technol. 143:174-202.

Valkeners, D., A. Théwis, F. Piron, and Y. Beckers. 2004. Effect of imbalance between energy and nitrogen supplies on microbial protein synthesis and nitrogen metabolism in growing double-muscled Belgian blue bulls. J. Anim. Sci. 82:1818-1825.

van Duinkerken, G., G. André, M. C. J. Smits, G. J. Monteny, and L. B. J. Sebek. 2005. Effect of rumen degradable protein balance and forage type on bulk milk urea concentration and emission of ammonia from dairy cow houses. J. Dairy Sci. 88:1099-1112.

Van Es, A. J. H. 1978. Feed evaluation for ruminants. I. The systems in use from May 1977-onwards in the Netherlands. Livest. Prod. Sci. 5:331-345

Van Soest, P. J., J. B. Robertson, and B. A. Lewis. 1991. Methods for dietary fiber, neutral detergent fiber, and nonstarch polysaccharides in relation to animal nutrition. J. Dairy Sci. 74:3583-3597.

Waghorn, G. C., M. J. Ulyatt, A. John, and M. T. Fisher. 1987. The effect of condensed tannins on the site of digestion of amino acids and other nutrients in sheep fed on Lotus corniculatus. Br. J. Nutr. 57:115-126.

Wang, Y., B. P. Berg, L. R. Barbieri, D. M. Veira, and T. A. McAllister. 2006a. Comparison of alfalfa and mixed alfalfa-sainfoin pastures for grazing cattle: Effects on incidence of bloat, ruminal fermentation, and feed intake. Can. J. Anim. Sci. 86:383-392.

Wang, Y., P. Frutos, M. Y. Gruber, H. Ray, and T. A. McAllister. 2006b. In vitro ruminal digestion of anthocyanidin-containing alfalfa transformed with the maize $L c$ regulatory gene. Can. J. Plant Sci. 86:1119-1130.

Yu, P., D. A. Christensen, and J. J. McKinnon. 2003a. Comparison of the national research council-2001 model with the Dutch system (DVE/OEB) in the prediction of nutrient supply to dairy cows from forages. J. Dairy Sci. 86:2178-2192.

Yu, P., D. A. Christensen, J. J. McKinnon, and J. D. Markert. 2003b. Effect of variety and maturity stage on chemical composition, carbohydrate and protein subfractions, in vitro rumen degradability and energy values of timothy and alfalfa. Can. J. Anim. Sci 83:279-290

Yu, P., K. Hart, and L. Du. 2009. An investigation of carbohydrate and protein degradation ratios, nitrogen to energy synchronization and hourly effective rumen digestion of barley: Effect of variety and growth year. J. Anim. Physiol. Anim. Nutr. (Berl.) 93:555-567.

Yu, P., J. J. McKinnon, and D. A. Christensen. 2004. The ratios of degradation characteristics of forages in the rumen of dairy cows: Effect of variety and stage of maturity. J. Sci. Food Agric. $84: 179-189$ 